암모니아 浸出工程 技術開發 動向

\author{
柳庚槿・ 中金鉉仲* \\ 韓國海洋大學校 에너지資源工學科, *全北大學校 資源에너지工學科
}

\title{
Development of Ammoniacal Leaching Processes; A Review
}

\author{
Kyoungkeun Yoo and "Hyunjung Kim* \\ Department of Energy \& Resources Engineering, Korea Maritime University \\ *Department of Mineral Resources \& Energy Engineering, Chonbuk National University
}

\section{요 약}

암모니아 습식제련공정은 철과 칼슘의 용해를 억제하며 구리 등의 금속을 선택적으로 침출이 가능한 장점이 있어 구리, 금, 니켈 및 코발트 등의 금속을 선택적으로 침출하기 위한 연구가 수행되어왔다. 이 글에서는 모터스크랩과 폐인쇄회로기판으로부터 구리의 선택적 침출, 티오황산염 사용 등 시안의 대체 및 저감을 위한 금의 암모니아침출, 산화니켈광 및 망간단괴처리공정 중간산물로부 터 니켈과 코발트를 회수하기 위한 암모니아침출 기술개발동향을 정리하고 국내 연구개발방향을 제시하고자 하였다.

주제어 : 암모니아 침출, 구리, 금, 니켈, 코발트

\begin{abstract}
Selective leaching processes for copper, gold, nickel, and cobalt have been investigated because there is an advantage of ammoniacal hydrometallurgy that metal such as copper could be selectively extracted restricting the dissolution of iron or calcium. In the present article, the studies for selective ammoniacal leaching of copper from motor scraps and waste printed circuit boards (PCBs), for ammoniacal leaching of gold to decrease the amount of cyanide used or to substitute cyanide by thiosulfate, and for ammoniacal leaching to recover nickel and cobalt from nickel oxide ore and intermidiate obtained from manganese nodule treatment process were summarized and further studies were proposed for domestic technology development for ammoniacal hydrometallurgy processes.
\end{abstract}

Key words : Ammoniacal leaching, Copper, Gold, Nickel, Cobalt

\section{1. 서 론}

광물 또는 폐기물 (순환자원)로부터 금속을 회수하기 위하여 대량의 처리가 가능한 건식제련공정이 사용되어
왔으나 $\mathrm{CO}_{2}$ 또는 $\mathrm{SO}_{2}$ 등 유해가스 발생 우려가 있고, 대규모 건설로 인하여 초기 투자비용이 높은 단점이 있 다. ${ }^{1)}$ 습식제련공정은 유해가스 발생 우려가 적으며, 소 규모로 공정운영이 가능하여 초기 투자비용이 낮기 때

\footnotetext{
* Received : July 16, 2012 - Revised : September 10, $2012 \cdot$ Accepted : September 25, 2012

₹Corresponding Author : Hyunjung Kim (E-mail: kshjkim@jbnu.ac.kr)

Department of Mineral Resources and Energy Engineering, Chonbuk National University, 664-14, Duckjin-Dong, Duckjin-Gu, Jeonju, Jeonbuk 561-756, Korea

Tel : +82-63-270-2370 / Fax : +82-63-270-2366

(C) The Korean Institute of Resources Recycling. All rights reserved. This is an open-access article distributed under the terms of the Creative Commons Attribution Non-Commercial License (http://creativecommons.org/licenses/by-nc/3.0/), which permits unrestricted non-commercial use, distribution and reproduction in any medium, provided the original work is properly cited.
} 
문에 건식제련공정의 대안으로서 연구되어 왔다. ${ }^{1)}$ 습식 제련공정은 일반적으로 침출-분리정제-전해채취 공정으 로 구성되며 $\mathrm{pH}$ 조건에 따라 산침출과 알칼리침출로 대별할 수 있다. 알칼리 영역에서 침출공정을 운영하는 경우 불순물로 존재하는 철과 칼슘의 용해를 억제할 수 있는 장점이 있으며 암모니아 또는 가성소다를 이용하 는 침출공정이 대표적이다. ${ }^{2)}$

Meng과 Han은 암모니아 습식제련에 관련된 총설에 서 암모니아 습식제련공정을 시기별로 다음과 같이 정 리하였다. ${ }^{2)}$ 암모니아의 의미 있는 상업적 생산은 1880 년대 석탄건류공정 중 부산물로서 생산된 것이며, 1913 년 상업생산시설이 건설되었다. 금속을 회수하기 위한 암모니아 습식제련공정은 1916년 구리를 회수하기 위 한 상업적 적용이 보고되었으며, Kennecott사와 Calumet \& Hecla사가 미국 알라스카와 북부 미시간에 각각 설치하였다. 1947년에 Sherritt Gordon사가 구리, 니켈, 코발트의 복합정광으로부터 각 금속을 회수하기 위해 고온고압 암모니아 침출기술을 개발하였고, 1954 년에 캐나다 알버타에 고온고압침출을 위한 오토클레이 브를 설치하고 개발기술을 적용하여 금속을 생산하였다. 1970년대 Arbiter 공정이 아나콘다에서 개발되었으며 이 공정 역시 고온고압조건에서 암모니아 침출을 수행하며 주로 구리정광으로부터 구리를 회수하였다. 1924년에 저품위 산화광으로부터 니켈과 코발트를 회수하기 위해 암모니아-탄산암모늄 용액을 사용한 Caron 공정이 소개 되었으며, 쿠바의 Nicaro, 필리핀의 Marinduque, 그리 고 호주의 Queensland에서 사용되었다. 또 다른 성공적 인 암모니아침출공정은 캐나다 Ontario의 Copper Cliff에 $\mathrm{INCO}$ 사에 의해 설치된 공정으로서 자황철광 (pyrrhotite) 정광으로부터 니켈, 코발트, 구리를 회수하기 위해 전처 리 공정 후 암모니아-탄산암모늄 용액을 침출액으로서 사용하였다.
우리나라는 대표적인 자원빈국으로서 금속자원의 $95 \%$ 이상을 수입에 의존하고 있다. ${ }^{3)}$ 금속수요가 큰 국내산 업의 지속적인 발전을 위해서는 안정적인 금속자원의 수 급체계 확립이 매우 중요하다. 생활수준 향상 및 정보화 기술의 발전에 따라 전기전자제품의 사용수명이 단축되 어 폐전기전자기기 (waste electric and electronic equipments)의 발생량이 급증하고 있으며 세계적으로 매년 2백 만-5백만톤이 발생하고 있는 것으로 알려져 있다. ${ }^{4)}$ 이 로부터 금속을 회수하기 위하여 EU는 2020년까지 $50 \%$ 이상의 폐금속을 회수하도록 의무를 부과하고 있 으며, 우리나라는 현재 $35.8 \%$ 인 재활용율을 2013년(1단 계)까지 55\%, 2020년까지(2단계) $75 \%$ 까지 달성하기 위해 도시광석(폐금속자원) 재활용 대책을 마련하였다. ${ }^{3)}$

인쇄회로기판 (printed circuit boards, $\mathrm{PCBs}$ )은 대표 적인 폐금속자원으로서 Table $1^{5)}$ 에 나타낸 것과 같이 다량의 유가금속을 함유하고 있다. 금속 성분 중 철과 알루미늄, 구리의 함량이 높게 나타나고 있으나 습식제 련공정에서 철과 알루미늄은 경제적으로 회수하기 어렵 기 때문에 주로 구리와 귀금속이 회수대상으로 연구되 어 왔다. ${ }^{6,7)}$ 암모니아 침출공정에서는 철의 용해를 억제 시키며 구리와 귀금속을 용해시키는 것이 가능하기 때 문에 도시광석으로부터 금속성분을 회수하기 위한 효율 적인 공정운영이 가능하다. Table 2에 국가과학기술정 보센터 (www.ndsl.kr)에서 '암모니아'와 ‘침출'로 검색 하여 얻은 암모니아 침출공정 관련 국내논문 및 연구보 고서 검색 결과를 나타내었다. ${ }^{8-15)}$ 암모니아 침출기술이 선진국에서 체계적으로 연구되어온 것에 비하여 국내의 암모니아 습식제련공정 연구는 단발적으로 진행되어오 다 최근 순환자원연구분야에 소수의 논문이 발표된 실 정이다. 이 글에서는 암모니아 습식제련기술 개발동향 을 금속성분 별로 정리하여 향후 국내에서의 암모니아 습식제련기술 연구 방향을 제시하고자 하였다.

Table 1. Weight and value distribution of metals in several electronic equipments. ${ }^{5)}$

\begin{tabular}{|c|c|c|c|c|c|c|c|}
\hline Weight- $\%$ & $\mathrm{Fe}$ & $\mathrm{Al}$ & $\mathrm{Cu}$ & Plastics & Ag [ppm] & Au [ppm] & Pt [ppm] \\
\hline TV-board & $28 \%$ & $10 \%$ & $10 \%$ & $28 \%$ & 280 & 20 & 10 \\
\hline PC-board & $7 \%$ & $5 \%$ & $20 \%$ & $23 \%$ & 1000 & 250 & 110 \\
\hline Mobile phone & $5 \%$ & $1 \%$ & $13 \%$ & $56 \%$ & 1380 & 350 & 210 \\
\hline Value-share & $\mathrm{Fe}$ & $\mathrm{Al}$ & $\mathrm{Cu}$ & $\mathrm{Sum} \mathrm{PM}$ & $\mathrm{Ag}$ & $\mathrm{Au}$ & $\mathrm{Pd}$ \\
\hline TV-board & $4 \%$ & $11 \%$ & $42 \%$ & $43 \%$ & $8 \%$ & $27 \%$ & $8 \%$ \\
\hline PC-board & $0 \%$ & $1 \%$ & $14 \%$ & $85 \%$ & $5 \%$ & $65 \%$ & $15 \%$ \\
\hline Mobile phone & $0 \%$ & $0 \%$ & $7 \%$ & $93 \%$ & $5 \%$ & $67 \%$ & $21 \%$ \\
\hline
\end{tabular}

J. of Korean Inst. Resources Recycling Vol. 21, No. 5, 2012 
Table 2. Domestic research for ammoniacal leaching.

\begin{tabular}{|c|c|c|}
\hline 저자 및 책임자 & 제목 및 내용 & 연도 \\
\hline 김종화 등8) & 습식제련공정에 의한 석유화학 폐촉매로부터 니켈의 회수 & 2010 \\
\hline 김지혜 등 9$)$ & $\begin{array}{l}\text { WC-Co 초경합금 슬러지로부터 왕수처리를 이용한 텅스텐의 회수 - 중간생성물인 텅스텐산 } \\
\text { 을 암모니아로 용해 }\end{array}$ & 2010 \\
\hline 박경호 등10) & 암모니아 용액중에서 바나듐의 용해와 침전거동 & 2008 \\
\hline 김은영 등1) & 오리멀젼회로부터 제조된 중간생성물로부터 바나듐과 니켈의 선택적 침출 & 2006 \\
\hline 김종화 등12) & 국내 석유공장의 탈황 폐촉매로부터 유가금속의 회수에 관한 연구 & 1995 \\
\hline 김동선 등13) & 황화광의 액상산화 아연광의 암모니아 용액중에서의 습식산화 & 1966 \\
\hline 이응조 ${ }^{14)}$ & 함 중금속 전기 아크로 분진의 습식제련 개발에 관한 연구 & 1998 \\
\hline 이동휘 ${ }^{15)}$ & $\begin{array}{l}\text { 인도네시아 저품위 Laterite로부터 니켈의 회수에 관한 연구: 침출액으로부터 니켈의 } \\
\text { 용매추출 및 전기화학적 침출에 관한 연구 }\end{array}$ & 1985 \\
\hline
\end{tabular}

\section{2. 암모니아의 특징}

암모니아는 상온에서 무색이고 특유의 자극적인 냄새 가 있는 기체이며, 분자는 $\mathrm{N}$ 을 정점으로 하는 3 각추이 고 밑면은 한변의 길이를 $1.63 \AA$ 으로 하는 정삼각형이 다. ${ }^{16)} \mathrm{N}$ 과 $\mathrm{H}$ 의 결합길이는 $1.015 \AA$ 이며 $\mathrm{HNH}$ 의 결합 각은 $106.6^{\circ}$ 이다. ${ }^{16)}$ 암모니아의 융점은 $-77.7^{\circ} \mathrm{C}$, 비등점 $-33.4^{\circ} \mathrm{C}$, 밀도 $0.771 \mathrm{~g} / \mathrm{L}\left(0^{\circ} \mathrm{C}, 1 \mathrm{~atm}\right)$, 비중 0.676 (액체)으로 알려져 있다. ${ }^{16)}$

암모니아는 물에 잘 녹는 것으로 알려져 있으며 수용 액에서 다음과 같이 반응하여 암모늄이온이 생성된다. ${ }^{17)}$

$$
\mathrm{NH}_{3}+\mathrm{H}^{+}=\mathrm{NH}_{4}^{+}
$$

이 식의 평형상수는 다음과 같이 나타낼 수 있다.

$$
\mathrm{K}=\frac{\left[\mathrm{NH}_{4}^{+}\right]}{\left[\mathrm{NH}_{3}\right]\left[\mathrm{H}^{+}\right]}
$$

Eq. (2)의 평형상수(Equilibrium constant) 값은 표준 조건에서 $10^{9.24}$ 로서 ${ }^{2)}$ 물에 대한 용해도가 매우 높은 것 을 알 수 있다.

암모니아는 많은 금속이온과 착이온을 형성하는 것으로 알려져 있다. Table 3에 은 $(\mathrm{Ag})$, 금 $(\mathrm{Au})$, 카드뮴 $(\mathrm{Cd})$, 코발트 $(\mathrm{Co})$, 구리 $(\mathrm{Cu})$, 니켈 $(\mathrm{Ni})$, 팔라듐 $(\mathrm{Pd})$, 아연 $(\mathrm{Zn})$ 의 암모니아 착이온 종류와 표준조건에서의 표준 Gibbs 자유에너지를 나타내었다.,18,19) Table 4에는 Table 3의 열역학적 데이터를 이용하여 착이온 형성 반 응식에 대한 표준 Gibbs자유에너지를 게산한 결과를 나 타내었으며 대부분의 Gibbs 자유에너지가 음부호를 나 타내고 있어 착이온의 형성이 용이하게 이루어지는 것
을 시사하고 있다.

즉, 암모니아는 물에 대한 용해도가 매우 클 뿐 아니 라, 금속이온과 착이온 형성능력도 높아 금속이온의 용 해도를 증가시키는 것이 가능하다. 따라서 암모니아를 용매로 이용할 경우 반응기의 용적을 줄일 수 있어 경 제적인 습식제련공정 운영을 기대할 수 있다.

\section{3. 금속별 암모니아 습식제련공정}

\section{1. 구리 (Copper)}

구리는 암모니아가 존재할 경우, Table 4에서 나타난 바와 같이 구리 1 가 이온(Cuprous ion, $\mathrm{Cu}^{+}$)과 구리 2 가 이온(Cupric ion, $\left.\mathrm{Cu}^{2+}\right)$ 이 각각 암모니아와 착이온 을 형성한다. Fig. 1에 총 암모니아 농도가 7 몰, 구리 의 활동도가 0.5 일 경우의 Eh-pH diagram을 나타내었 다. ${ }^{20,21)}$ 알카리 조건에서 $\mathrm{Cu}\left(\mathrm{NH}_{3}\right)_{4}{ }^{2+}$ 과 $\mathrm{Cu}\left(\mathrm{NH}_{3}\right)_{2}{ }^{+}$이 온의 지배적인 영역이 나타나며 $\mathrm{Cu}\left(\mathrm{NH}_{3}\right)_{4}{ }^{2+}$ 이온은 Eq. (3)에서 알 수 있듯이 구리금속의 산화제로서 작용 하고 반응 생성물로서 $\mathrm{Cu}\left(\mathrm{NH}_{3}\right)_{2}{ }^{+}$이온이 생성되는 것 으로 알려져 있다. ${ }^{21-27)}$

$$
\mathrm{Cu}+\mathrm{Cu}\left(\mathrm{NH}_{3}\right)_{4}^{2+}=2 \mathrm{Cu}\left(\mathrm{NH}_{3}\right)_{2}^{+}
$$

Koyama 등은 ${ }^{20)}$ Eq. (3) 반응의 표준산화환원전위를 $0.20 \mathrm{~V}$ 로 계산하였다. 반응생성물인 $\mathrm{Cu}\left(\mathrm{NH}_{3}\right)_{2}{ }^{+}$이온은 산소 등을 이용하여 $\mathrm{Cu}\left(\mathrm{NH}_{3}\right)_{4}{ }^{2+}$ 이온으로 산화시켜 침 출제로 재이용이 가능하므로 효율적인 공정 운영이 가 능하다. Sedzimir와 Bujanska ${ }^{28)}$ 는 Rotating Disc법을 이용하여 황산암모늄용액에서 금속구리의 암모니아 침 출 거동을 조사하였고, 초기 $\mathrm{Cu}\left(\mathrm{NH}_{3}\right)_{4}{ }^{2+}$ 이온농도가 높 
Table 3. Thermodynamic data for various ammines and other species. ${ }^{2,18,19)}$

\begin{tabular}{|c|c|c|c|c|c|}
\hline Species & $\Delta \mathrm{G}^{0} \mathrm{~kJ} / \mathrm{mol}$ & Species & $\Delta \mathrm{G}^{0} \mathrm{~kJ} / \mathrm{mol}$ & Species & $\Delta \mathrm{G}^{0} \mathrm{~kJ} / \mathrm{mol}$ \\
\hline $\mathrm{Au}^{+}$ & 176 & $\mathrm{Cd}\left(\mathrm{NH}_{3}\right)^{2+}$ & -118.928 & $\mathrm{Cu}\left(\mathrm{NH}_{3}\right)_{4}^{2+}$ & -111.390 \\
\hline $\mathrm{Au}^{3+}$ & 440 & $\mathrm{Cd}\left(\mathrm{NH}_{3}\right)_{2}^{+}$ & -159.129 & $\mathrm{Ni}\left(\mathrm{NH}_{3}\right)^{2+}$ & -87.814 \\
\hline $\mathrm{Ag}^{+}$ & 77.16 & $\mathrm{Cd}\left(\mathrm{NH}_{3}\right)_{3}^{+}$ & -191.248 & $\mathrm{Ni}\left(\mathrm{NH}_{3}\right)_{2}^{2+}$ & -126.842 \\
\hline $\mathrm{Cd}^{2+}$ & -77.612 & $\mathrm{Cd}\left(\mathrm{NH}_{3}\right)_{4}^{+}$ & -226.549 & $\mathrm{Ni}\left(\mathrm{NH}_{3}\right)_{3}^{2+}$ & -162.981 \\
\hline $\mathrm{Cu}^{+}$ & 50.3 & $\mathrm{Co}\left(\mathrm{NH}_{3}\right)^{2+}$ & -92.546 & $\mathrm{Ni}\left(\mathrm{NH}_{3}\right)_{4}^{2+}$ & -196.022 \\
\hline $\mathrm{Cu}^{2+}$ & 65.7 & $\mathrm{Co}\left(\mathrm{NH}_{3}\right)_{2}^{2+}$ & -127.722 & $\mathrm{Ni}\left(\mathrm{NH}_{3}\right)_{5}^{2+}$ & -22.647 \\
\hline $\mathrm{Ni}^{2+}$ & -46.4 & $\mathrm{Co}\left(\mathrm{NH}_{3}\right)_{3}^{2+}$ & -159.548 & $\mathrm{Ni}\left(\mathrm{NH}_{3}\right)_{6}^{2+}$ & -252.931 \\
\hline $\mathrm{Pd}^{2+}$ & 176.5 & $\mathrm{Co}\left(\mathrm{NH}_{3}\right)_{4}^{2+}$ & -189.698 & $\mathrm{Pd}\left(\mathrm{NH}_{3}\right)^{2+}$ & 109.045 \\
\hline $\mathrm{Zn}^{2+}$ & -147.16 & $\mathrm{Co}\left(\mathrm{NH}_{3}\right)_{5}^{2+}$ & -220.352 & $\mathrm{~Pb}\left(\mathrm{NH}_{3}\right)_{2}^{2+}$ & 31.575 \\
\hline $\mathrm{Co}^{2+}$ & -53.76 & $\mathrm{Co}\left(\mathrm{NH}_{3}\right)_{6}^{2+}$ & -162.898 & $\mathrm{~Pb}\left(\mathrm{NH}_{3}\right)_{3}^{2+}$ & -37.898 \\
\hline $\mathrm{NH}_{3}$ & -26.633 & $\mathrm{Cu}\left(\mathrm{NH}_{3}\right)^{++}$ & -10.469 & $\mathrm{~Pb}\left(\mathrm{NH}_{3}\right)_{4}^{2+}$ & -103.382 \\
\hline $\mathrm{Ag}\left(\mathrm{NH}_{3}\right)^{+}$ & 31.658 & $\mathrm{Cu}\left(\mathrm{NH}_{3}\right)_{2}^{+}$ & -65.285 & $\mathrm{Zn}\left(\mathrm{NH}_{3}\right)^{2+}$ & -186.600 \\
\hline $\mathrm{Ag}\left(\mathrm{NH}_{3}\right)_{2}^{+}$ & -17.253 & $\mathrm{Cu}\left(\mathrm{NH}_{3}\right)^{2+}$ & 15.578 & $\mathrm{Zn}\left(\mathrm{NH}_{3}\right)_{2}^{2+}$ & -226.299 \\
\hline $\mathrm{Ag}\left(\mathrm{NH}_{3}\right)_{2}^{+}$ & -41.353 & $\mathrm{Cu}\left(\mathrm{NH}_{3}\right)_{2}^{2+}$ & -30.486 & $\mathrm{Zn}\left(\mathrm{NH}_{3}\right)_{3}^{2+}$ & -266.415 \\
\hline $\mathrm{Ag}\left(\mathrm{NH}_{3}\right)_{4}^{+}$ & 64.489 & $\mathrm{Cu}\left(\mathrm{NH}_{3}\right)_{3}^{2+}$ & -73.199 & $\mathrm{Zn}\left(\mathrm{NH}_{3}\right)_{4}^{2+}$ & -304.648 \\
\hline
\end{tabular}

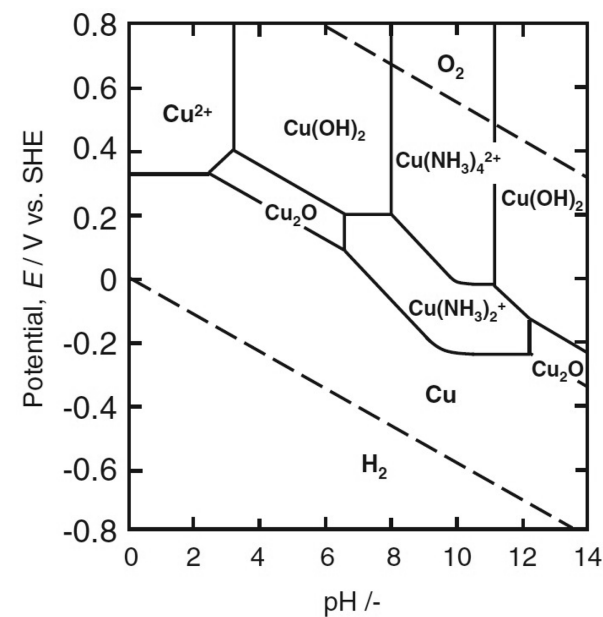

Fig. 1. Eh-pH diagram of the $\mathrm{Cu}-\mathrm{NH}_{3}-\mathrm{H}_{2} \mathrm{O}$ system at $298 \mathrm{~K}$ calculated by assuming that the activity of copper is 0.5 and that the total concentration of the ammonia is $7.0 \mathrm{~mol} / \mathrm{L}^{20,21)}$

을수록 $15-50^{\circ} \mathrm{C}$ 온도범위에서 온도가 증가할수록 구리 의 침출속도가 증가하며, 암모니아의 농도는 침출속도 에 큰 영항을 미치지 않는다고 보고하였다. ${ }^{28)}$ Fig. 2에 Sedzimir와 Bujanska가 보고한 구리 침출율에 미치는 온도의 영향을 나타내었다. ${ }^{28)}$

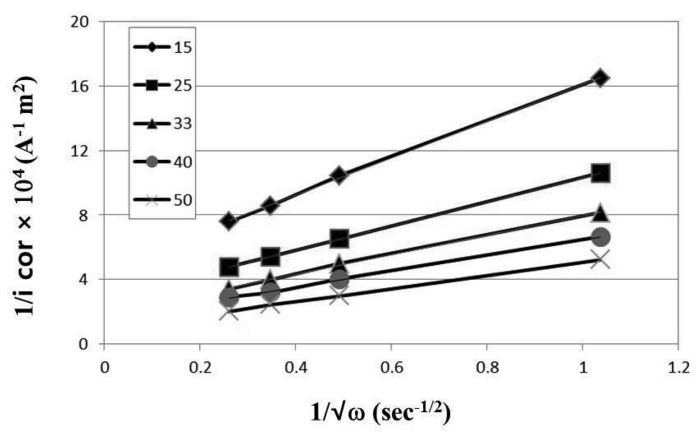

Fig. 2. Dependence of the reciprocal value of the corrosion velocity of copper on the reciprocal value of the square root of the disc rotation frequency. ${ }^{28)}$

암모니아 침출공정의 가장 큰 장점은 철과 같은 성분 과 공존하는 구리, 니켈, 코발트, 아연 및 카드뮴 등의 성분을 선택적으로 용해 가능하다는 것이다. ${ }^{29)}$ 이와 같 은 성질을 이용하여 철과 구리를 분리하는 연구가 수행 되었다. ${ }^{22-26,30)}$ Majima 등22)과 Nigo 등30)은 모터스크 랩으로부터 철과 구리를 분리하여 회수하기 위해 암모 니아 침출공정을 연구하였다. 이 연구에서 암모니아 $\left(\mathrm{NH}_{3}\right)$ 농도를 증가시킴에 따라 침출속도가 증가하여 Sedzimir와 Bujanska ${ }^{28)}$ 의 실험결과와 상반된 결과를 나 타내었으며, 침출용액을 공기에 노출시켜 $\mathrm{Cu}\left(\mathrm{NH}_{3}\right)_{2}{ }^{+}$이 
Table 4. Gibbs free energies for reactions between metal ion and ammonia.

\begin{tabular}{|c|c|c|}
\hline Species & Equation & $\Delta \mathrm{G}^{0} \mathrm{~kJ} / \mathrm{mol}$ \\
\hline $\mathrm{Ag}\left(\mathrm{NH}_{3}\right)^{+}$ & $\mathrm{Ag}^{+}+\mathrm{NH}_{3}=\mathrm{Ag}\left(\mathrm{NH}_{3}\right)^{+}$ & -18.869 \\
\hline $\mathrm{Ag}\left(\mathrm{NH}_{3}\right)_{2}^{+}$ & $\mathrm{Ag}^{+}+\mathrm{NH}_{3}=\mathrm{Ag}\left(\mathrm{NH}_{3}\right)_{2}^{+}$ & -41.147 \\
\hline $\mathrm{Au}\left(\mathrm{NH}_{3}\right)_{2}^{+}$ & $\mathrm{Au}^{+}+2 \mathrm{NH}_{3}=\mathrm{Au}\left(\mathrm{NH}_{3}\right)_{2}^{+}$ & -164.087 \\
\hline $\mathrm{Au}\left(\mathrm{NH}_{3}\right)_{4}^{3+}$ & $\mathrm{Au}^{+}+2 \mathrm{NH}_{3}=\mathrm{Au}\left(\mathrm{NH}_{3}\right)_{2}^{+}$ & -268.979 \\
\hline $\mathrm{Cd}\left(\mathrm{NH}_{3}\right)^{2+}$ & $\mathrm{Cd}^{2+}+\mathrm{NH}_{3}=\mathrm{Cd}\left(\mathrm{NH}_{3}\right)^{2+}$ & -14.683 \\
\hline $\mathrm{Cd}\left(\mathrm{NH}_{3}\right)_{2}^{2+}$ & $\mathrm{Cd}^{2+}+2 \mathrm{NH}_{3}=\mathrm{Cd}\left(\mathrm{NH}_{3}\right)_{2}^{2+}$ & -28.251 \\
\hline $\mathrm{Cd}\left(\mathrm{NH}_{3}\right)_{3}^{2+}$ & $\mathrm{Cd}^{2+}+3 \mathrm{NH}_{3}=\mathrm{Cd}\left(\mathrm{NH}_{3}\right)_{3}^{2+}$ & -33.737 \\
\hline $\mathrm{Cd}\left(\mathrm{NH}_{3}\right)_{4}^{2+}$ & $\mathrm{Cd}^{2+}+4 \mathrm{NH}_{3}=\mathrm{Cd}\left(\mathrm{NH}_{3}\right)_{4}^{2+}$ & -42.405 \\
\hline $\mathrm{Co}\left(\mathrm{NH}_{3}\right)^{2+}$ & $\mathrm{Co}^{2+}+\mathrm{NH}_{3}=\mathrm{Co}\left(\mathrm{NH}_{3}\right)^{2+}$ & -12.153 \\
\hline $\mathrm{Co}\left(\mathrm{NH}_{3}\right)_{2}^{2+}$ & $\mathrm{Co}^{2+}+2 \mathrm{NH}_{3}=\mathrm{Co}\left(\mathrm{NH}_{3}\right)_{2}^{2+}$ & -20.696 \\
\hline $\mathrm{Co}\left(\mathrm{NH}_{3}\right)_{3}^{2+}$ & $\mathrm{Co}^{2+}+3 \mathrm{NH}_{3}=\mathrm{Co}\left(\mathrm{NH}_{3}\right)_{3}^{2+}$ & -25.889 \\
\hline $\mathrm{Co}\left(\mathrm{NH}_{3}\right)_{4}^{2+}$ & $\mathrm{Co}^{2+}+4 \mathrm{NH}_{3}=\mathrm{Co}\left(\mathrm{NH}_{3}\right)_{4}^{2+}$ & -29.406 \\
\hline $\mathrm{Co}\left(\mathrm{NH}_{3}\right)_{5}^{2+}$ & $\mathrm{Co}^{2+}+5 \mathrm{NH}_{3}=\mathrm{Co}\left(\mathrm{NH}_{3}\right)_{5}^{2+}$ & -33.427 \\
\hline $\mathrm{Co}\left(\mathrm{NH}_{3}\right)_{6}^{2+}$ & $\mathrm{Co}^{2+}+6 \mathrm{NH}_{3}=\mathrm{Co}\left(\mathrm{NH}_{3}\right)_{6}^{2+}$ & 50.66 \\
\hline $\mathrm{Cu}\left(\mathrm{NH}_{3}\right)^{+}$ & $\mathrm{Cu}^{+}+\mathrm{NH}_{3}=\mathrm{Cu}\left(\mathrm{NH}_{3}\right)^{+}$ & -34.136 \\
\hline $\mathrm{Cu}\left(\mathrm{NH}_{3}\right)_{2}^{+}$ & $\mathrm{Cu}^{+}+2 \mathrm{NH}_{3}=\mathrm{Cu}\left(\mathrm{NH}_{3}\right)_{2}^{+}$ & -62.319 \\
\hline $\mathrm{Cu}\left(\mathrm{NH}_{3}\right)^{2+}$ & $\mathrm{Cu}^{2+}+\mathrm{NH}_{3}=\mathrm{Cu}\left(\mathrm{NH}_{3}\right)^{2+}$ & -23.489 \\
\hline $\mathrm{Cu}\left(\mathrm{NH}_{3}\right)_{2}^{2+}$ & $\mathrm{Cu}^{2+}+2 \mathrm{NH}_{3}=\mathrm{Cu}\left(\mathrm{NH}_{3}\right)_{2}^{2+}$ & -42.92 \\
\hline $\mathrm{Cu}\left(\mathrm{NH}_{3}\right)_{3}^{2+}$ & $\mathrm{Cu}^{2+}+3 \mathrm{NH}_{3}=\mathrm{Cu}\left(\mathrm{NH}_{3}\right)_{3}^{2+}$ & -59 \\
\hline $\mathrm{Cu}\left(\mathrm{NH}_{3}\right)_{4}^{2+}$ & $\mathrm{Cu}^{2+}+4 \mathrm{NH}_{3}=\mathrm{Cu}\left(\mathrm{NH}_{3}\right)_{4}^{2+}$ & -70.558 \\
\hline $\mathrm{Ni}\left(\mathrm{NH}_{3}\right)^{2+}$ & $\mathrm{Ni}^{2+}+\mathrm{NH}_{3}=\mathrm{Ni}\left(\mathrm{NH}_{3}\right)^{2+}$ & -14.781 \\
\hline $\mathrm{Ni}\left(\mathrm{NH}_{3}\right)_{2}^{2+}$ & $\mathrm{Ni}^{2+}+2 \mathrm{NH}_{3}=\mathrm{Ni}\left(\mathrm{NH}_{3}\right)_{2}^{2+}$ & -27.176 \\
\hline $\mathrm{Ni}\left(\mathrm{NH}_{3}\right)_{3}^{2+}$ & $\mathrm{Ni}^{2+}+3 \mathrm{NH}_{3}=\mathrm{Ni}\left(\mathrm{NH}_{3}\right)_{3}^{2+}$ & -36.682 \\
\hline $\mathrm{Ni}\left(\mathrm{NH}_{3}\right)_{4}^{2+}$ & $\mathrm{Ni}^{2+}+4 \mathrm{NH}_{3}=\mathrm{Ni}\left(\mathrm{NH}_{3}\right)_{4}^{2+}$ & -43.09 \\
\hline $\mathrm{Ni}\left(\mathrm{NH}_{3}\right)_{5}^{2+}$ & $\mathrm{Ni}^{2+}+5 \mathrm{NH}_{3}=\mathrm{Ni}\left(\mathrm{NH}_{3}\right)_{5}^{2+}$ & 156.918 \\
\hline $\mathrm{Ni}\left(\mathrm{NH}_{3}\right)_{6}^{2+}$ & $\mathrm{Ni}^{2+}+6 \mathrm{NH}_{3}=\mathrm{Ni}\left(\mathrm{NH}_{3}\right)_{6}^{2+}$ & -46.733 \\
\hline $\mathrm{Pb}\left(\mathrm{NH}_{3}\right)^{2+}$ & $\mathrm{Pb}^{2+}+\mathrm{NH}_{3}=\mathrm{Pb}\left(\mathrm{NH}_{3}\right)^{2+}$ & -40.822 \\
\hline $\mathrm{Pb}\left(\mathrm{NH}_{3}\right)_{2}^{2+}$ & $\mathrm{Pb}^{2+}+\mathrm{NH}_{3}=\mathrm{Pb}\left(\mathrm{NH}_{3}\right)_{2}^{2+}$ & -91.659 \\
\hline $\mathrm{Pb}\left(\mathrm{NH}_{3}\right)_{3}^{2+}$ & $\mathrm{Pb}^{2+}+\mathrm{NH}_{3}=\mathrm{Pb}\left(\mathrm{NH}_{3}\right)_{3}^{2+}$ & -134.499 \\
\hline $\mathrm{Pb}\left(\mathrm{NH}_{3}\right)_{4}^{2+}$ & $\mathrm{Pb}^{2+}+\mathrm{NH}_{3}=\mathrm{Pb}\left(\mathrm{NH}_{3}\right)_{4}^{2+}$ & -173.35 \\
\hline $\mathrm{Zn}\left(\mathrm{NH}_{3}\right)^{2+}$ & $\mathrm{Zn}^{2+}+\mathrm{NH}_{3}=\mathrm{Zn}\left(\mathrm{NH}_{3}\right)^{2+}$ & -12.807 \\
\hline $\mathrm{Zn}\left(\mathrm{NH}_{3}\right)_{2}^{2+}$ & $\mathrm{Zn}^{2+}+2 \mathrm{NH}_{3}=\mathrm{Zn}\left(\mathrm{NH}_{3}\right)_{2}^{2+}$ & -25.873 \\
\hline $\mathrm{Zn}\left(\mathrm{NH}_{3}\right)_{3}^{2+}$ & $\mathrm{Zn}^{2+}+3 \mathrm{NH}_{3}=\mathrm{Zn}\left(\mathrm{NH}_{3}\right)_{3}^{2+}$ & -39.356 \\
\hline $\mathrm{Zn}\left(\mathrm{NH}_{3}\right)_{4}^{2+}$ & $\mathrm{Zn}^{2+}+4 \mathrm{NH}_{3}=\mathrm{Zn}\left(\mathrm{NH}_{3}\right)_{4}^{2+}$ & -50.956 \\
\hline
\end{tabular}

온을 $\mathrm{Cu}\left(\mathrm{NH}_{3}\right)_{4}{ }^{2+}$ 이온으로 산화시키는 것이 가능함을 확인하였다.22) 황산구리 $\left(\mathrm{CuSO}_{4}\right) 0.5 \mathrm{~mol} / \mathrm{L}$, 암모니아 $\left(\mathrm{NH}_{3}\right) 5 \mathrm{~mol} / \mathrm{L}$, 황산암모늄 $\left(\left(\mathrm{NH}_{4}\right)_{2} \mathrm{SO}_{4}\right) 1 \mathrm{~mol} / \mathrm{L}$ 의 $20 \mathrm{~L}$ 용액을 $8 \mathrm{~L} / \mathrm{min}$ 의 유량으로 순환시키며 별도의 교 반없이 $6.6 \mathrm{~kg}$ 의 시료를 침출시킬 때 $22.1 \mathrm{~kg} / \mathrm{m}^{3} / \mathrm{h}$ 의 속도로 구리가 침출된다고 보고하였다. ${ }^{22}$ 침출된 용액 을 산화시켜 지속적으로 산화제 $\left(\mathrm{Cu}\left(\mathrm{NH}_{3}\right)_{4}{ }^{2+}\right)$ 를 확보하 기 위해 용액을 순환시켰으며, 반응기에 침출용액을 아 래에서 위로 주입하는 상향침투법이 반응기의 윗부분에 서 스프레이로 분무하는 스프레이법에 비하여 효율이 높다는 사실도 보고되었다. ${ }^{30)}$

Zhou 등23-26)은 폐자동차 철스크랩에서 구리성분을 선 택적으로 침출시켜 회수하기 위한 암모니아 침출공정을 개발하였다. 이 공정에서 지속적인 산화제 확보를 위해 Eq. (4)와 같이 산소를 이용하여 $\mathrm{Cu}\left(\mathrm{NH}_{3}\right)_{2}{ }^{+}$이온을 $\mathrm{Cu}\left(\mathrm{NH}_{3}\right)_{4}{ }^{2+}$ 이온으로 산화시켰다.

$$
4 \mathrm{Cu}\left(\mathrm{NH}_{3}\right)_{2}^{+}+4 \mathrm{NH}_{3}+4 \mathrm{NH}_{4+}+\mathrm{O}_{2}=4 \mathrm{Cu}\left(\mathrm{NH}_{3}\right)_{4}^{2+}+2 \mathrm{H}_{2} \mathrm{O}
$$

Zhou 등 23-26)은 반응기에 산소를 주입하여 Eq. (4)과 같이 $\mathrm{Cu}\left(\mathrm{NH}_{3}\right)_{4}{ }^{2+}$ 이온을 지속적으로 생성하였으나, 암 모니아가 쉽게 증발되어 침출조건을 안정시키기 어렵기 때문에 안정적인 침출공정을 유지하기 위하여 산소를 순환시키는 폐쇄형 반응기(Oxygen Circulating Ammonia Leaching)를 개발하였다. 23-26) 이 반응기에서 초기 구리농도, 가스의 순환유량 및 반응온도를 증가시킴에 따라 구리의 침출속도가 증가한다고 보고하였다. ${ }^{23-26)}$

Table 1에서 알 수 있듯이 철과 구리는 인쇄회로기판 의 주요 금속성분이다. 폐인쇄회로기판 (Waste printed circuit board, WPCB)으로부터 구리를 회수하기 위한

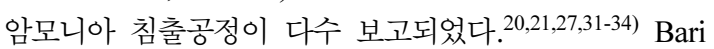
등은 인쇄회로기판으로부터 구리를 회수하기 위하여 다 양한 침출용액을 이용하여 침출실험을 진행하였다. ${ }^{34)}$ Fig. 3 에 암모니아 농도가 5 몰이고 각 침출시약의 농도 가 1 몰인 경우 구리의 침출율을 나타내었다. Fig. 3 에 서 과황산암모늄, 탄산암모늄, 질산암모늄, 염화암모늄, 황산암모늄 순으로 침출율이 높은 것을 알 수 있다.

일본의 산업총합기술연구소 (National Istitute of Advanced Industrial Science and Technology, AIST) 는 인쇄회로기판으로부터 구리를 회수하기 위한 에너지 절약형 습식제련공정을 개발하였다. ${ }^{20,21,27,31-33) ~} \mathrm{Fig}$. 4에 암모니아 습식제련공정의 개념도를 나타내었다. 침출공정 


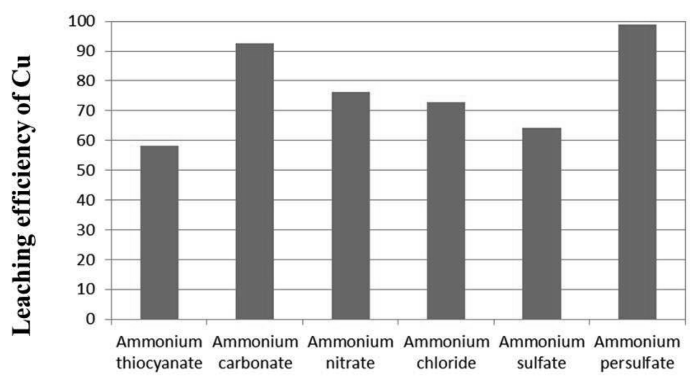

Fig. 3. Leaching efficiency of $\mathrm{Cu}$ with various type of leaching solution (leaching agent $1 \mathrm{~mol} / \mathrm{L}, \mathrm{NH}_{3} 5$ $\mathrm{mol} / \mathrm{L}$, initial $\mathrm{Cu}$ concentration $277.4 \mathrm{mg} / \mathrm{g}$ ). ${ }^{34)}$

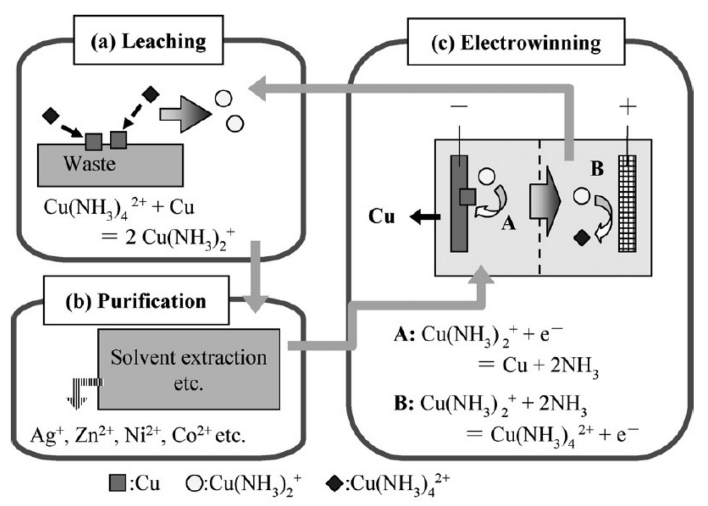

Fig. 4. Copper recovery process using ammoniacal alkaline solution proposed by AIST. ${ }^{31)}$

(Fig. 4(a))에서 폐인쇄회로기판 중의 구리는 $\mathrm{Cu}\left(\mathrm{NH}_{3}\right)_{4}{ }^{2+}$ 이온에 의해 Eq. (3)과 같이 침출되며, 침출용액 중의 은, 아연 등의 불순물은 용매추출 (Solvent extraciton) 공정에 의하여 제거된다. $\mathrm{Cu}\left(\mathrm{NH}_{3}\right)_{2}{ }^{+}$이온만을 포함한 정액은 전해공정 (Fig. 4(c))에서 다음 식과 같이 처리 된다. ${ }^{20,21,27,31-33)}$

$$
\begin{aligned}
& \mathrm{Cu}\left(\mathrm{NH}_{3}\right)_{2}^{+}+\mathrm{e}^{-}=\mathrm{Cu}+2 \mathrm{NH}_{3} \\
& \mathrm{Cu}\left(\mathrm{NH}_{3}\right)_{2}^{+}+2 \mathrm{NH}_{3}=\mathrm{Cu}\left(\mathrm{NH}_{3}\right)_{4}^{2+}+\mathrm{e}^{-}
\end{aligned}
$$

전해공정에서 Anode 전극에서 $\mathrm{Cu}\left(\mathrm{NH}_{3}\right)_{2}{ }^{+}$이온은 $\mathrm{Cu}\left(\mathrm{NH}_{3}\right)_{4}{ }^{2+}$ 이온으로 산화되며 산화된 $\mathrm{Cu}\left(\mathrm{NH}_{3}\right)_{4}{ }^{2+}$ 이 온은 침출공정으로 보내져 산화제로서 재사용되고, Cathode 전극에서 $\mathrm{Cu}\left(\mathrm{NH}_{3}\right)_{2}{ }^{+}$이온은 환원되어 구리로 석 출된다. ${ }^{27,31-33)}$ Koyama 등은 상기의 침출공정(Fig. 4(a))의 기초 침출거동을 조사하여, $\mathrm{Cu}\left(\mathrm{NH}_{3}\right)_{4}{ }^{2+}$ 이온농도가 높 을수록 인쇄회로기판 스크랩(scrap)의 크기가 작을수록

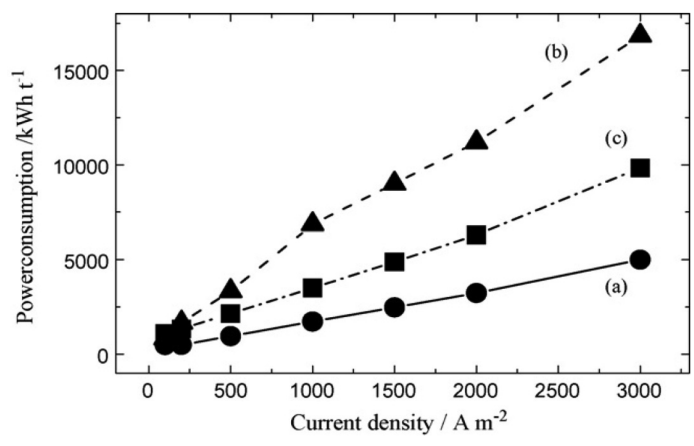

Fig. 5. Power consumption during the copper electrodeposition in the solution containing (a) $5 \mathrm{M} \mathrm{NH}_{3}$, $4 \mathrm{M} \mathrm{NH}_{4} \mathrm{Cl}$ and $0.5 \mathrm{M} \mathrm{Cu}_{2} \mathrm{O}$, (b) $5 \mathrm{M} \mathrm{NH}_{3}, 4 \mathrm{M}$ $\mathrm{NH}_{4} \mathrm{NO}_{3}$ and $0.5 \mathrm{M} \mathrm{Cu}_{2} \mathrm{O}$, and (c) $5 \mathrm{M} \mathrm{NH}_{3}, 2 \mathrm{M}$ $\left(\mathrm{NH}_{4}\right)_{2} \mathrm{SO}_{4}$ and $0.5 \mathrm{M} \mathrm{Cu}_{2} \mathrm{O}$. ${ }^{31)}$

구리의 침출율은 상승하고, $\mathrm{Cu}\left(\mathrm{NH}_{3}\right)_{2}{ }^{+}$이온의 농도와 반응온도를 증가시킬 경우에는 구리 침출율의 큰 변화 가 없었다고 보고하였다. ${ }^{30,31)} \mathrm{Oishi}$ 등은 불순물 제거공 정과 전해공정을 연구하였으며, ${ }^{27,31-33)}$ 다음과 같이 결 과를 보고하였다. 침출용액 중 존재하는 아연 $(\sim 1 \mathrm{~g} / \mathrm{L})$ 과 망간 $(\sim 0.1 \mathrm{~g} / \mathrm{L})$ 은 LIX 26을 용매로 이용한 용매추 출공정에서 $95 \%$ 제거할 수 있고, ${ }^{27)}$ 인산염(phosphate) 을 투입하여 납의 농도를 $5 \times 10^{-5} \mathrm{~mol} / \mathrm{L}$ 까지 낮추는 것이 가능하다고 보고하였다. ${ }^{33)}$ 또한 Oishi 등은 질산 암모늄, 염화암모늄, 황산암모늄 등 다양한 염을 사용한 용액에서 구리를 석출하기 위한 전력소비량을 조사하였 으며 (Fig. 5), 염화암모늄을 사용하였을 때 잔류밀도가 $200 \mathrm{~A} / \mathrm{m}^{2}$ 의 조건에서 $500 \mathrm{kWh} / \mathrm{t}$ 의 전력소비량이 도출 되었고 이는 기존 구리석출공정의 전력소비량의 $25 \%$ 에 불과하다고 보고하였다. ${ }^{31)}$

Chang과 Liu는 석유화학공장 폐수처리공정에서 발생 한 슬러지로부터 구리를 회수하기 위해 암모니아 침출 공정연구를 수행하였으며, $\mathrm{pH} 10$, 광액농도 $20 \mathrm{~g} / \mathrm{L}, 25$ 도에서 침출실험을 진행하였을 때 $94 \%$ 까지 침출되는 것을 확인하였다. ${ }^{35)}$

\section{2. 금 (Gold)}

금을 광물 또는 폐기물로부터 회수하기 위해 시안을 사용하는 청화법이 주로 사용되어왔으나 시안은 독성물 질이기 때문에 사용을 제한하는 지역이 증가하여 대안 침출제 (alternative lixiviant)에 대한 연구가 다수 수행 되어왔다. ${ }^{36,37)}$ Table 4 에 나타낸 바와 같이 금이온은 1 가 금이온 (Aurous ion, $\mathrm{Au}^{+}$)과 3 가 금이온 (Auric ion, 


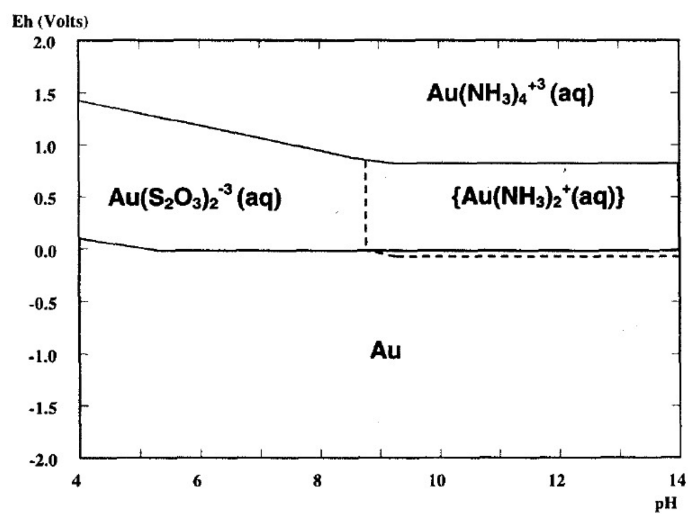

Fig. 6. Eh-pH diagram at high reagent concentration for Au$\mathrm{NH}_{3}-\mathrm{S}_{2} \mathrm{O}_{3}{ }^{2-}$ system (conditions: $5 \times 10^{-4} \mathrm{M} \mathrm{Au} ; 1 \mathrm{M}$ $\left.\mathrm{S}_{2} \mathrm{O}_{3}{ }^{2-} ; 1 \mathrm{M} \mathrm{NH}_{3} / \mathrm{NH}^{4+}, 0.05 \mathrm{M} \mathrm{Cu}^{2+}\right){ }^{38)}$

$\mathrm{Au}^{3+}$ )이 암모니아와 착이온을 형성한다. Fig. $6^{38)}$ 에서 알 수 있듯이 금은 알칼리영역에서 $\mathrm{Au}\left(\mathrm{NH}_{3}\right)_{4}{ }^{3+}$ 와 $\mathrm{Au}\left(\mathrm{NH}_{3}\right)_{2}{ }^{+}$가 안정적으로 나타나며, $\mathrm{Au}\left(\mathrm{NH}_{3}\right)_{4}{ }^{3+}$ 이온은 산화영역에서 $\mathrm{Au}\left(\mathrm{NH}_{3}\right)_{2}{ }^{+}$은 보다 낮은 산화영역에서 안 정적이다. 이와 같은 특성을 이용한 대안침출제는 티오 황산염 (thiosulfate, $\mathrm{S}_{2} \mathrm{O}_{3}{ }^{2-}$ )-암모니아 (ammonia, $\mathrm{NH}_{3}$ )2 가 구리이온 (cupric ion, $\mathrm{Cu}^{2+}$ ) 시스템, 시안 (cyanide, $\mathrm{CN}^{-}$)-암모니아 시스템 그리고 암모니아 고온고압침출로 알려져 있다. ${ }^{36,37)}$

티오황산염은 가장 대표적인 시안침출의 대안침출제로 서 알려져 있으며 현재까지 연구되어 출판된 대안침출제 연구의 $33 \%$ 를 차지한다고 보고되었다. ${ }^{38)}$ 티오황산염에 의 한 금침출은 다음 식과 같이 나타낼 수 있다. ${ }^{36-38)}$

$$
\begin{aligned}
& \mathrm{Au}+5 \mathrm{~S}_{2} \mathrm{O}_{3}^{2-}+\mathrm{Cu}\left(\mathrm{NH}_{3}\right)_{4}^{2+}= \\
& =\mathrm{Au}\left(5 \mathrm{~S}_{2} \mathrm{O}_{3}\right)_{2}^{3-}+4 \mathrm{NH}_{3}+\mathrm{Cu}\left(\mathrm{S}_{2} \mathrm{O}_{3}\right)_{3}^{5-} \\
& 2 \mathrm{Cu}\left(\mathrm{S}_{2} \mathrm{O}_{3}\right)_{3}^{5-}+8 \mathrm{NH}_{3}+\frac{1}{2} \mathrm{O}_{2}+\mathrm{H}_{2} \mathrm{O} \\
& 2 \mathrm{Cu}\left(\mathrm{NH}_{3}\right)_{4}^{2+}+2 \mathrm{OH}^{-}+6 \mathrm{~S}_{2} \mathrm{O}_{3}^{2-}
\end{aligned}
$$

식 (7)과 (8)에서 알 수 있듯이 구리이온은 금침출의 촉매로서 역할을 하며 식 (7)에서 산화제로서 역할을 하여 구리 1 가 이온으로 환원된 후, 식 (8)과 같이 산 소에 의해 구리 2 가 이온으로 다시 산화되어 산화제로 서 이용된다.

Breuer와 Jeffrey는 rotating electrochemical quartz crystal microbalance (REQCM)과 같은 전기화학적 방

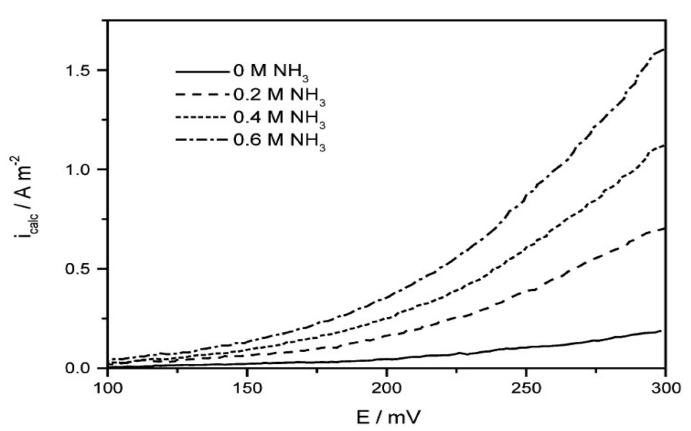

Fig. 7. Effect of ammonia concentration on the voltammograms for gold oxidation in thiosulfate solutions. ${ }^{40)}$

법으로 티오황산염-암모니아-구리이온 시스템에서 금의 침출거동을 조사하였다. ${ }^{39-41)}$ 암모니아 농도의 영향을 조 사한 결과, Fig. 7과 같이 암모니아 농도 증가에 따라 금의 침출율 증가가 관찰되었으며, 암모니아가 첨가되 지 않으면 금 침출속도가 현저히 저하되었다. ${ }^{40)}$ 구리이 온, 산소, 코발트이온을 산화제로서 비교하였을 때 구리 이온이 가장 높은 효율을 나타내었으며 $2 \mathrm{mM}$ 정도가 가장 좋은 효율을 나타냈다. ${ }^{40)}$ 금의 침출속도는 구리농 도와 반응온도가 높을 때 증가하며 이 때 반응은 화학 적으로 제어되며 구리의 농도가 낮고 온도가 $30^{\circ} \mathrm{C}$ 일 경우 구리이온의 확산속도에 의해 반응이 제어된다. ${ }^{39)}$ Breuer와 Jeffrey는 티오황산염-암모니아-구리이온 시스 템에서 금의 최적 침출조건으로서 $0.4 \mathrm{M} \mathrm{NH}_{3}, 0.1 \mathrm{M}$ $\mathrm{S}_{2} \mathrm{O}_{3}{ }^{2-}, \mathrm{pH}>11.4,30^{\circ} \mathrm{C}$ 를 제시하였다. ${ }^{41)}$

Senanayake와 Zhang은 금나노입자 $(20 \mathrm{~nm})$ 를 이용하 여 티오황산염-암모니아-구리이온 시스템에서 금의 용 해거동을 조사하였다. ${ }^{42-43)} \mathrm{pH}$ 가 증가함에 따라 금의 용 해속도도 함께 증가하였으며 이는 $\mathrm{pH}$ 가 증가하면 free $\mathrm{NH}_{3}$ 의 농도가 증가하여 결과적으로 2 가 구리이온을 안 정시켜 구리이온의 농도를 증가시키는 것이 이유로 보 고되었다. ${ }^{42-43)}$ 또한 공존이온 또는 염의 영향을 조사하 기 위해 다양한 첨가제를 사용하여 분석을 진행하였으 며, 금의 용해율에 기여하는 순서를 $\mathrm{AgNO}_{3}>\mathrm{NaCl}>$ $\mathrm{Na}_{2} \mathrm{SO}_{4}>$ none $-\mathrm{Na}_{2} \mathrm{CO}_{3}>\mathrm{NaNO}_{3}>\mathrm{Pb}\left(\mathrm{NO}_{3}\right)_{2}>$ $\mathrm{Na}_{2} \mathrm{~S}_{4} \mathrm{O}_{6}-\mathrm{Na}_{2} \mathrm{~S}_{3} \mathrm{O}_{6}>\mathrm{Na}_{2} \mathrm{SO}_{3}$ 로 보고하였으며, ${ }^{43)}$ 일 부 결과를 Fig. 8에 나타내었다. ${ }^{43)}$

Feng과 van Deventer는 금박(gold foil)과 금광(gold ore)을 대상으로 티오황산염-암모니아-구리이온 시스템 에서 금의 침출거동을 조사하였다. ${ }^{44,45)}$ 황철석(pyrite, $\mathrm{FeS}_{2}$ )은 용액 중의 티오황산염을 trithionate로 변환시키 


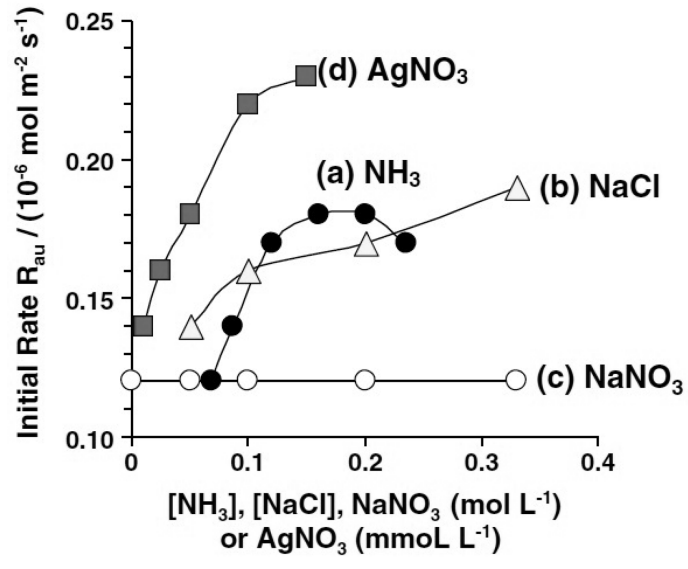

Fig. 8. Effect of $\mathrm{NaNO} 3, \mathrm{NaCl}, \mathrm{AgNO} 3$ or free $\mathrm{NH} 3$ on initial dissolution rate of colloidal gold at $25^{\circ} \mathrm{C}$ and particle size $20 \mathrm{~nm}$ : (a) $\mathrm{pH}$ change from $8, .9$ to $11.0,\left[\mathrm{NH}_{3}+\mathrm{NH}_{4}^{+}\right]=0.24 \mathrm{M},\left[\mathrm{Na}_{2} \mathrm{~S}_{2} \mathrm{O}_{3}\right]=40 \mathrm{mM}$, $\left[\mathrm{Cu}^{2+}\right]=2 \mathrm{mM}(\mathrm{b}, \mathrm{c}, \mathrm{d}) \mathrm{pH}=9.5,\left[\mathrm{NH}_{3}+\mathrm{NH}_{4}{ }^{+}\right]=0.12$ $\left.\mathrm{M},\left[\mathrm{Na}_{2} \mathrm{~S}_{2} \mathrm{O}_{3}\right]=20 \mathrm{mM},\left[\mathrm{Cu}^{2+}\right]=1.5 \mathrm{mM}^{43}\right)$

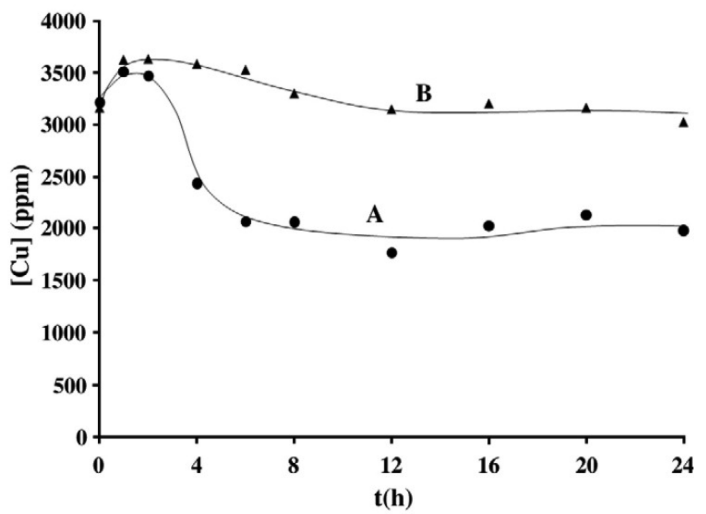

Fig. 9. Copper concentration during the leaching of the sabinas concentrate in thiosulfate solutions of the following composition: $0.025 \mathrm{M}$ EDTA, $0.2 \mathrm{M}$ $\mathrm{S}_{2} \mathrm{O}_{3}{ }^{2-}, 0.05 \mathrm{M} \mathrm{Cu}^{2+}$, and $0.6 \mathrm{M} \mathrm{NH}_{3}$, (A) Without phosphate and (B) with $0.1 \mathrm{M}\left(\mathrm{NH}_{4}\right)_{2} \mathrm{HPO}_{4}{ }^{46}{ }^{4}$

는 촉매 역할을 하기 때문에 금침출을 저해하며 황산을 첨가하여 황철석의 영향을 감소시킬 수 있다고 보고하 였다. ${ }^{44)}$ 또한 calcium thiosulfate, sodium thiosulfate, ammonium thiosulfate의 영향을 비교한 결과 금의 용 해속도는 calcium thiosulfate에서 가장 빠르며, ammonium thiosulfate에서 금을 침출시킬 때 thiosulfate의 소비가 가장 큰 것으로 보고하였다. ${ }^{45)}$ Alonso-Gomez와 Lapidus는 인 산염(phosphate)를 첨가할 때 금침출 시 납의 용출 억제 가 가능하다고 보고하였고 (Fig. 9), ${ }^{46)}$ Arima 등은 산화제

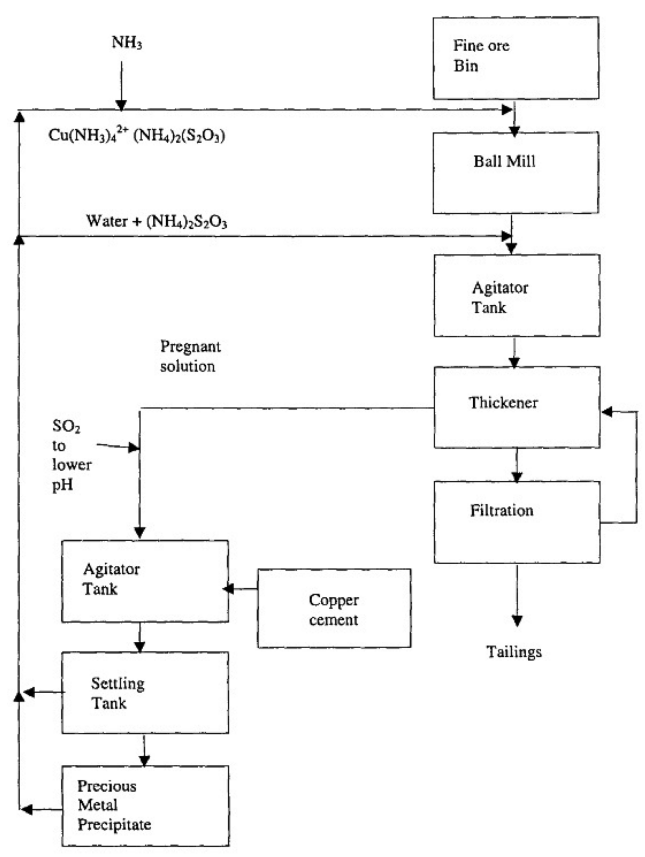

Fig. 10. Flow chart of pilot plant layout that existed at LaColorada, in the State of Senora, Mexico. ${ }^{48)}$

로서 구리대신 니켈을 사용하는 연구를 진행하였으며, ${ }^{47)}$ Zipperian과 Raghavan은 유문암(Rhyolite ore)로부터 금 침출거동을 조사하고 $22 \%$ thiosulfate, $7 \% \mathrm{NH}_{3}, 1.5 \%$ $\mathrm{CuSO}_{4}, 60^{\circ} \mathrm{C}$ 의 침출조건에서 한시간 동안 $90 \%$ 의 금이 침출된 것을 보고하였다. ${ }^{48)}$

Fig. 10에 멕시코 LaColorada에 설치된 티오황산염암모니아-구리이온 시스템을 이용한 금침출 pilot plant 의 공정도를 나타내었다. ${ }^{38)}$ 시안을 대체하는 금침출제 로서 티오황산염-암모니아-구리이온 시스템이 가장 많 이 연구되어왔으나 현재까지 상용화된 예는 극히 적은 것으로 알려져 있다. ${ }^{36-38)}$ 티오황산염을 이용하여 금을 침출하는 공정 중 티오황산염이 polythionate로 변환되 어 티오황산염의 소비량이 증가하기 때문에 경제적인 운영이 어렵다는 것이 핵심적인 문제이다. ${ }^{36-38)}$ 예를 들 어 구리이온에 의한 티오황산염는 다음 식과 같이 tetrathionate로 변환된다. ${ }^{47)}$

$$
\begin{gathered}
2\left[\mathrm{Cu}\left(\mathrm{NH}_{3}\right)_{4}\right]^{2+}+2 \mathrm{~S}_{2} \mathrm{O}_{3}^{2-} \\
=2\left[\mathrm{Cu}\left(\mathrm{NH}_{3}\right)_{2}\right]^{+}+\mathrm{S}_{4} \mathrm{O}_{6}^{2-}+4 \mathrm{NH}_{3}
\end{gathered}
$$

티오황산염-암모니아-구리이온 시스템은 이러한 단점 에도 불구하고, 시안 소모를 촉진시키는 구리가 다량 함 


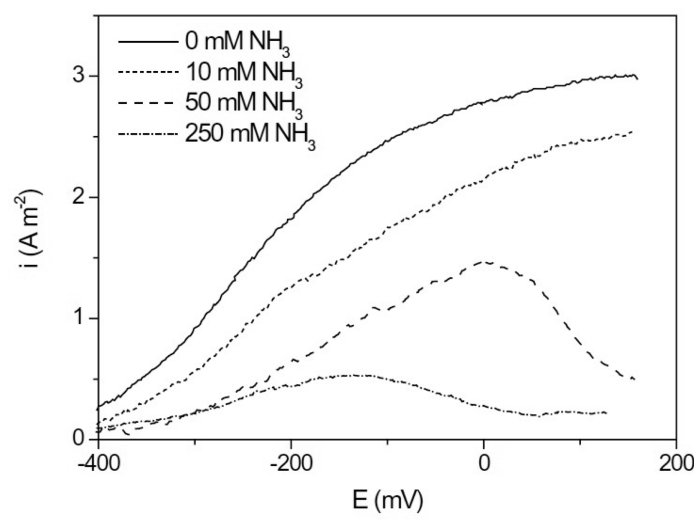

Fig. 11. Linear sweep voltammogram showing the oxidation of gold in $1 \mathrm{mM}$ cyanide solutions in the presence of various quantities of ammonia. ${ }^{50}$

유된 광물, carbonaceous preg-robbing 물질, 난용성 황화물 (refractory sulfides) 등에 적용 가능할 것으로 기대되고 있다. ${ }^{37)}$ 향후 구리 또는 산소에 의한 티오황 산염의 산화방지와 금 피복에 의한 금침출률 저하 방지 등의 개선 연구가 필요하다.

시안의 사용을 줄이기 위하여 시안과 암모니아를 병 용하는 연구가 진행되었다.99-51) 1990년대 서호주 (Western Austrailia)의 Paris dump의 산화구리광미와 모리타니 (Mauritania) Akjoujt의 광미를 처리하기 위해 상용규모의 공정이 운영되었으나 침출기구에 대한 이해 부족으로 실패하였다. ${ }^{51)}$ Zheng 등과 Jeffrey 등의 연구 에 의하면 시안-암모니아 금침출 시스템에서 구리와 암 모니아 어느 한 쪽이 없고 다른 한 쪽의 농도를 증가 시키면 오히려 금침출율이 감소하며 (Fig. 11), 구리 1 가이온과 암모니아농도의 증가도 금침출율을 감소시키 는 것으로 보고하였다. ${ }^{49-50)}$ Muir의 보고에 따른 전형적 인 침출조건은 $3 \% \mathrm{Cu}, 2.5-5.0 \mathrm{~kg} / \mathrm{t} \mathrm{NaCN}, 1.1 \mathrm{~kg} / \mathrm{t}$ $\mathrm{NH}_{3}$ 이며 이 조건에서 약 $70-80 \%$ 의 침출율을 나타내는 것으로 보고하였다. ${ }^{51}$

시안 또는 티오황산염과 병용하지 않고 암모니아만을 용매로 이용하여 금을 침출하기 위한 연구가 다수 수행 되었다. ${ }^{52-55)}$ Aylmore는 지금까지 연구되어 출판된 시안 의 대체제 연구 중 약 $2 \%$ 를 차지한다고 보고하였다. ${ }^{56)}$ 열역학적 이론의 계산에서는 상온의 암모니아 용액에서 금 침출이 가능하나 Fig. 12에서 알 수 있듯이 실제로 는 $80^{\circ} \mathrm{C}$ 이상에서 침출이 시작되며 $120^{\circ} \mathrm{C}$ 이상으로 온도를 증가시켜야 반응이 원활히 진행되는 것으로 보 고하였다. ${ }^{54)}$ 반응온도가 $200^{\circ} \mathrm{C}$, 암모니아 농도가 $3 \mathrm{M}$,

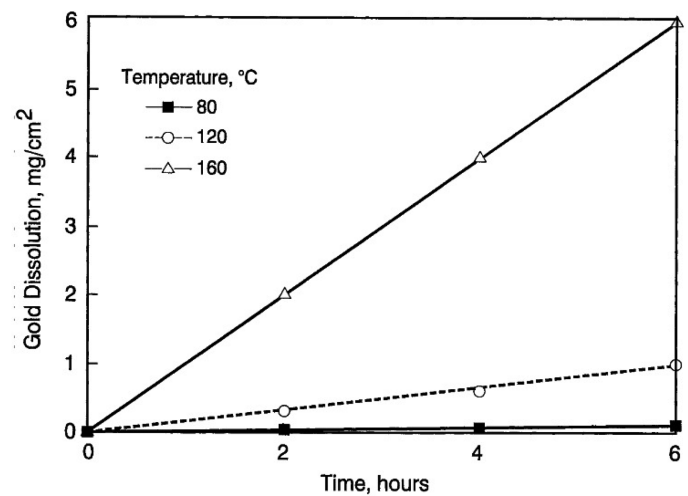

Fig. 12. The initial gold dissolution as a function of leaching time at various temperature. $\left(\mathrm{NH}_{3}\right)_{f}, 3.0 \mathrm{~mol} / \mathrm{dm}^{3}$; $\left(\mathrm{NH}_{4}\right)_{2} \mathrm{SO}_{4}, 0.5 \mathrm{~mol} / \mathrm{dm}^{3}$; cupric ammine, 0.157 $\mathrm{mol} / \mathrm{dm}^{3}$; oxygen partial pressure, $400 \mathrm{kPa}{ }^{54)}$

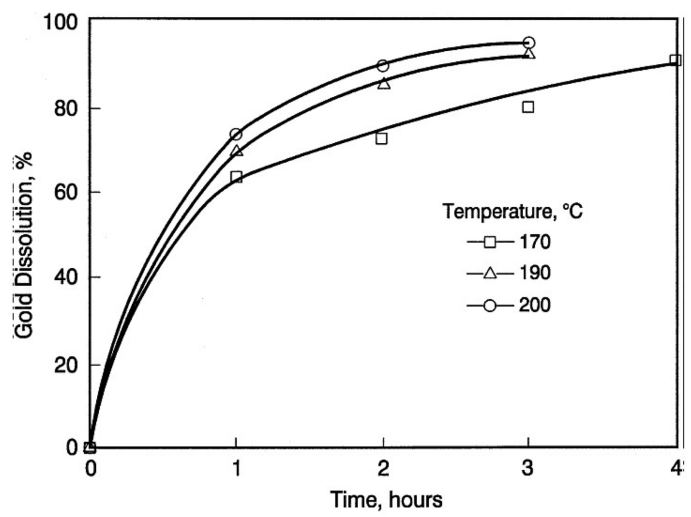

Fig. 13. The initial gold dissolution as a function of leaching time at various temperature. $\left(\mathrm{NH}_{3}\right)_{f}, 3.0 \mathrm{~mol} / \mathrm{dm}^{3}$; $\left(\mathrm{NH}_{4}\right)_{2} \mathrm{SO}_{4}, 0.5 \mathrm{~mol} / \mathrm{dm}^{3}$; cupric ammine, 0.157 $\mathrm{mol} / \mathrm{dm}^{3}$; oxygen partial pressure, $400 \mathrm{kPa}{ }^{54)}$

황산암모늄 농도가 $0.5 \mathrm{M}$, 구리아민농도가 $0.157 \mathrm{M}$, 산 소분압이 $400 \mathrm{kPa}$ 일 때에 2 시간 동안 $90 \%$ 의 금 침출 이 가능하였으며 (Fig. 13), ${ }^{54)} \mathrm{pH}$ 는 9까지 증가시킬 경 우 금의 용해도는 증가하고 그 이상으로 증가시킬 경우 는 침출율에 큰 차이가 없는 것으로 나타났다. ${ }^{53)}$ 구리 아민이온은 가장 효율적인 산화제이며 구리 2가이온을 이용할 경우 활성화에너지는 $61 \mathrm{~kJ} / \mathrm{mol}^{\circ}$ 이고 ${ }^{33)}$ 구리이온 대신 요오드를 사용할 경우 활성화에너지는 $46 \mathrm{~kJ} / \mathrm{mol}$ 로 보고되었다. ${ }^{55)}$

\section{3. 니켈과 코발트 (Nickel and cobalt)}

Fig. 14와 Table 3에 나타낸 바와 같이 니켈과 코발 트는 암모니아와 다양한 착이온을 형성하며 알칼리 조 

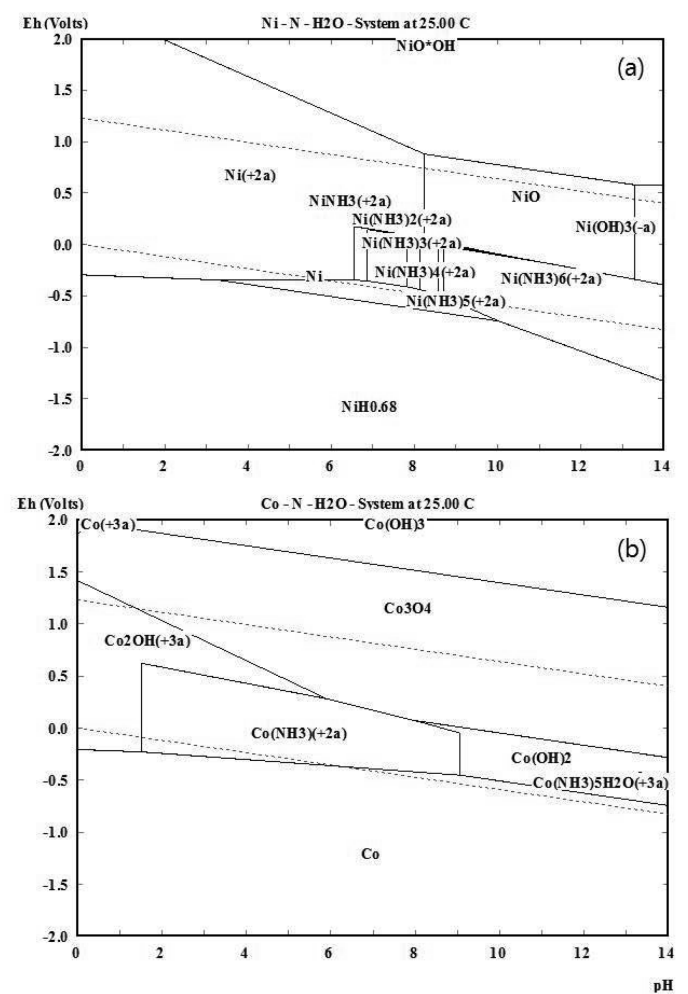

Fig. 14. Eh-pH diagrams for (a) $\mathrm{Ni}-\mathrm{NH}_{3}$ and (b) $\mathrm{Co}-\mathrm{NH}_{3}$ at $25^{\circ} \mathrm{C}$ and the concentrations of $\mathrm{Ni}, \mathrm{Co}$, and $\mathrm{NH}_{3}$ are $0.0001,0.0001$ and $1 \mathrm{M}$, respectively.

건에서 안정적으로 존재한다. 니켈과 코발트를 함유하 는 대표적인 광석은 Laterite이며 니켈의 산화물형태는 세계 니켈매장량의 $85 \%$ 를 차지하는 것으로 알려져 있 다. ${ }^{56)}$ 산화니켈광으로부터 니켈과 코발트를 회수하기 위 한 대표적인 공정은 Caron process이며 환원배소처리 후 암모니아를 이용한 침출로 니켈과 코발트를 회수한 다. ${ }^{57-59)}$

Caron process를 이용한 니켈 및 코발트 침출공정에서 침출율을 개선하기 위한 연구가 다수 수행되었다. ${ }^{56-60)}$ Murdoch 대학의 Nicol 교수연구팀은 Caron process에 서 니켈 침출에 미치는 여러 가지 첨가제 및 침출의 전기화학적 거동을 관찰하였으며, ${ }^{57-58)}$ 니켈의 함유량이 $45 \%$ 인 $\mathrm{Fe}-\mathrm{Ni}$ 합금의 암모니아 침출율을 증가시키는 첨 가제의 영향은 $\mathrm{S}_{2} \mathrm{O}_{3}{ }^{2-} / \mathrm{Cu}(\mathrm{II}) / \mathrm{O}_{2}>\mathrm{S}_{2} \mathrm{O}_{3}{ }^{2-} / \mathrm{Co}(\mathrm{III}) / \mathrm{O}_{2}$ $>\mathrm{S}_{2} \mathrm{O}_{3}{ }^{2-} / \mathrm{O}_{2}>\mathrm{O}_{2}>>\mathrm{HS}^{-} / \mathrm{O}_{2}$ 의 순이였다. ${ }^{48)}$ 또한 니 켈과 코발트는 티오황산염이 존재할 때 황화물 형태로, 티오황산염이 없는 경우 금속으로 석출된다고 보고하였 다. ${ }^{47)}$ Jandova와 Pedlik은 철과 니켈의 비율이 침출율
에 많은 영향을 미치며 $6.7,35,52 \%$ 의 니켈함량을 나 타내는 $\mathrm{Fe}-\mathrm{Ni}$ 합금의 침출을 진행하여 니켈함유량이 증 가할수록 침출율이 증가한다고 보고하였다. ${ }^{59)}$ 니켈과 코 발트를 니켈광으로부터 침출하기 위해서는 환원배소공정 이 필수적이며 Bhuntumkomol 등과 Chander와 Sharma는 이 전처리공정이 니켈과 코발트 침출에 매우 큰 영향을 미친다고 보고하였다. ${ }^{56,60)}$ Bhuntumkomol 등은 $1073 \mathrm{~K}$ 보다 $673 \mathrm{~K}$ 에서 환원배소된 시료가 11 배 빠른 침출속 도를 나타낸다고 보고하였고, ${ }^{56)}$ Chander와 Sharma는 환원배소공정 뿐 아니라 냉각시에도 주의가 필요하며, 특히 냉각할 때 재산화가 발생한다고 보고하며, 형성된 환원배소산물 중 $(\mathrm{NiFe}) \mathrm{O}>\mathrm{Fe}>\mathrm{NiFe}>\mathrm{Fe}_{3} \mathrm{O}_{4}$ 순 으로 침출이 잘 이루어진다고 보고하였다. ${ }^{60)}$

니켈광의 침출 후 다양한 금속이온을 분리정제하는 단계에서도 암모니아 침출공정이 활용되었다. ${ }^{61,62)}$ Laterite 침출액으로부터 니켈과 코발트를 각각 분리하 기 위해 니켈에 비하여 코발트가 일정 조건에서 알루미 늄과 쉽게 공침한다는 성질을 이용하여 $\mathrm{pH} 10,0.5 \mathrm{M}$ $\mathrm{NH}_{3 \text { total }}$ (ammonium hydroxide/ammonium nitrate) 용 액에서 알루미늄과 공침시킨 후, 침전물로부터 $\mathrm{pH} 10$, 2 몰 $\mathrm{NH}_{3}$ 용액에서 니켈과 코발트를 침출하는 실험이 수 행되었으며, Han 등은 침전물의 aging에 따라 활성화에 너지는 코발트의 경우 $10.5-26.8 \mathrm{~kJ} / \mathrm{mol}$, 니켈의 경우 15.0-38.9 kJ/mol로 계산되었다고 보고하였다. ${ }^{61)}$ Katsiapi 등은 Laterite 침출액으로부터 망간과 코발트를 용매추 출한 후 침전시킨 코발트-망간 수산화침전물에 대해 암 모니아-탄산암모늄을 이용하여 코발트의 선택적 침출을 수행하고, $\mathrm{NH}_{3} /\left(\mathrm{NH}_{4}\right)_{2} \mathrm{CO}_{3}=200 \mathrm{~g} / 200 \mathrm{~g}, 10 \%$ 광액농 도의 조건에서 코발트는 $93 \%$ 회수되고, 망간은 $0.05 \%$ 정도 침출되어 선택적 침출이 가능함을 보고하였다. ${ }^{62)}$

육상에 분포된 고품위 자원이 고갈되어감에 따라 대 체자원의 개발이 요구되고 있으며, 해저광물자원에 대 한 연구가 활발히 이루어지고 있다. ${ }^{63)}$ 특히 망간단괴는 수심 4 천에서 5 천 $\mathrm{m}$ 의 해저에 덩어리 형태로 발견되며 망간 뿐 아니라 니켈과 코발트 등도 포함되어 있어 망 간단괴로부터 니켈과 코발트를 회수하는 연구가 다수 진행되었다. ${ }^{64-67)}$ 한국지질자원연구원의 박경호 박사 연 구팀은 망간단괴로부터 유가금속을 회수하기 위해 망간 단괴를 전처리(pyrometallurgical reduction roasting \& smelting-sulphidation)하여 얻어진 $\mathrm{Cu}-\mathrm{Ni}-\mathrm{Co}-\mathrm{Fe}$ 매트를 $2 \mathrm{M} \mathrm{NH}_{4} \mathrm{OH}, 2 \mathrm{M}\left(\mathrm{NH}_{4}\right)_{2} \mathrm{SO}_{4}, 213$ psi pressure, $200^{\circ} \mathrm{C}$ 의 최적 침출조건에서 1 시간 동안 침출한 결과 $93.8 \%$ $\mathrm{Cu}, 85.3 \% \mathrm{Ni}, 76.5 \% \mathrm{Co}$ 가 회수된 결과를 보고하였 


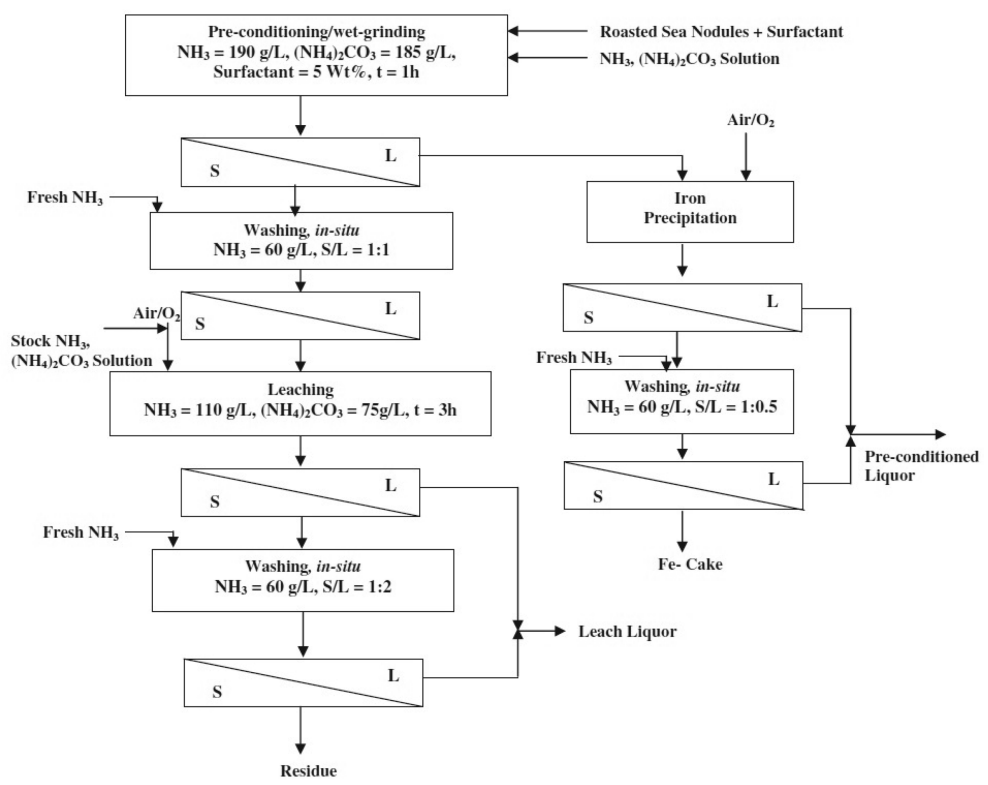

Fig. 15. Schematic diagram of the leaching flow-sheet proposed by NML. ${ }^{67)}$

다. ${ }^{64)}$ Niinae 등은 고코발트망간각을 ammonium thiosulfate 또는 amonium sulfite로 환원침출한 결과, 각각의 농도를 증가시킬 경우, ammonium thiosulfate의 경우 $\mathrm{Mn}, \mathrm{Co}, \mathrm{Ni}, \mathrm{Cu}$ 의 침출농도가 증가하였고, ammonium sulfite의 경우 $\mathrm{Co}, \mathrm{Ni}, \mathrm{Cu}$ 의 침출농도가 증가하였으며, 이는 $\mathrm{pH}$ 8.5-9.5의 범위에서 망간이 $\left(\mathrm{NH}_{4}\right)_{2} \mathrm{Mn}\left(\mathrm{SO}_{3}\right)_{2} \mathrm{H}_{2} \mathrm{O}$ 로 침전되기 때문이라고 보고하였 다. ${ }^{65)}$ 인도의 국가제련연구소(National Metallurgical Laboratory, NML)는 polymetallic 망간단괴로부터 유가금속 을 회수하기 위하여 Fig. 15 와 같은 공정을 제안하였다. ${ }^{67)}$ 이 공정은 1) 계면활성제를 투입 후 농암모니아용액에서 망간단괴의 preconditioning과 습식분쇄공정, 2) 공기주입에 의한 망간과 철 성분의 침전, 3) preconditioning 잔사의 침출로 이루어져 있으며, $95 \% \mathrm{Cu}, 94 \% \mathrm{Ni}, 80 \% \mathrm{Co}$ 의 침출율이 달성되었다고 보고하였다. ${ }^{66,67)}$

니켈산화광과 망간단괴 이외에도 니켈이온배터리, 석유 화학 폐촉매, 금속표면처리 슬러지 등 폐기물로부터 니켈 을 회수하기 위해 암모니아 침출공정이 연구되었다. ${ }^{68-70)}$ Demidov와 Krasovitskaya는 니켈이온배터리의 폐전극으 로부터 니켈분말의 침출거동을 조사하였으며, $70-80^{\circ} \mathrm{C}$ 의 조건에서 다양한 암모니아용액의 조합 $\left(2 \mathrm{M} \mathrm{NH} \mathrm{NH}_{4} \mathrm{OH}\right.$ 와 $1 \mathrm{M} \mathrm{NH} \mathrm{NH}_{4} \mathrm{NO}_{3}, 2 \mathrm{M} \mathrm{NH} \mathrm{NH}_{4} \mathrm{OH}$ 와 $1 \mathrm{M} \mathrm{NH} \mathrm{NH}_{4} \mathrm{Cl}, 1.5 \mathrm{M}$ $\mathrm{NH}_{4} \mathrm{OH}$ 와 $1 \mathrm{M} \quad\left(\mathrm{NH}_{4}\right)_{2} \mathrm{SO}_{4}, 1.5 \quad \mathrm{M} \quad \mathrm{NH}_{4} \mathrm{OH}$ 와 $1 \mathrm{M}$ $\left.\left(\mathrm{NH}_{4}\right)_{2} \mathrm{CO}_{3}\right)$ 조건에서 active paste 상태에서는 10-20분

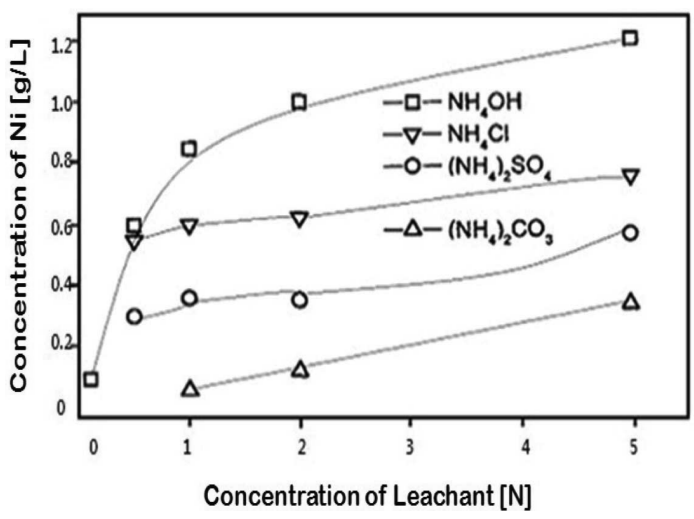

Fig. 16. The effect of leachant on the leaching efficiency of $\mathrm{Ni}^{8}{ }^{8}$

동안, lamella fragment 상태에서는 1-2시간의 침출반응 에 의해 $90 \%$ 정도의 니켈 침출율을 달성하였다. ${ }^{68)}$ 김 종화 등은 석유화학 폐촉매로부터 니켈을 회수하기 위 하여 암모니아 침출실험을 진행하였으며, $20 \%$ 광액농 도, $70-80^{\circ} \mathrm{C}, 300 \mathrm{rpm}$ 교반속도의 조건에서 2 시간 동 안 침출실험을 진행한 결과 Fig. 16 과 같이 $5 \mathrm{M}$ 의 $\mathrm{NH}_{4} \mathrm{OH}$ 를 사용하였을 때 가장 높은 침출율을 나타내었 다. ${ }^{8,12}$ Salhi는 금속표면처리공정에서 발생한 금속수산 화물 슬러지로부터 니켈과 구리를 회수하기 위하여 총 암모니아농도와 $\mathrm{pH}$ 를 주요 인자로 하여 이론적 계산과 
실험을 수행하였고, $\mathrm{pH}$ 8-11구간에서 암모니아 총농도 가 $6 \mathrm{M}$ 일 때 니켈과 구리의 침출율이 최대가 된다고 보고하였다. ${ }^{69)}$

\section{4. 맺음말}

이 글에서는 암모니아와 금속이온 사이의 착이온 형 성 등 화학적 특성을 정리하고, 구리, 금, 니켈과 코발 트 등의 암모니아 습식제련공정 사례를 정리하여 향후 암모니아 습식제련공정 국내 연구에 도움이 되고자 하 였다.

구리의 경우 모터스크랩과 폐인쇄회로기판으로부터 구리를 침출시키는 연구가 대표적이며, 철과 같은 금속 으로부터 선택적인 구리의 회수가 가능하였다. 금의 경 우 금광 또는 금스크랩으로부터 금을 회수하기 위해 사 용되는 시안을 저감하거나 대체하기 위한 연구가 다수 진행되었으며, 티오황산염 사용, 고온고압 암모니아 침 출, 시안과 암모니아 병용 등의 공정이 개발되었으나 현 재까지 상용화된 공정은 매우 드물다. 니켈과 코발트의 경우 주로 산화물 형태의 산화광 또는 망간단괴 처리공 정의 중간산물로부터 니켈 및 코발트의 암모니아 침출 공정이 연구되어왔으며, 코발트의 낮은 침출율과 기타 금속성분의 분리를 위한 추가적인 연구가 필요하다.

암모니아습식제련공정은 철 및 칼슘 성분의 용해를 억제하며 구리 등의 금속을 선택적으로 침출이 가능한 장점이 있으나 증발하는 성질을 제어하지 못하면 공정 중 암모니아의 손실이 클 수 있다는 점이 우려되어 이 를 극복하기 위한 침출장치 고안 및 공정 개발이 필요 하다. 또한 금의 암모니아침출공정의 경우 티오황산염 의 손실을 최소화하는 연구가 요구된다. 암모니아는 구 리, 금, 니켈과 코발트 이외에도 은, 팔라듐, 아연 등 다양한 금속과 착이온 형성이 가능하므로 향후 광석 또 는 폐기물로부터 금속을 회수하기 위한 암모니아침출공 정 연구가 지속되리라 판단된다.

\section{감사의 글}

본 연구는 한국지질자원연구원 주요사업 '희유금속[ 백금족(Pt, Pd, Rh), Co, Ni, Sn] 재자원화를 위한 하 이브리드 공정개발'의 일환으로 수행되었으며, 원활한 연구진행을 위해 지원을 해주신 관계자들께 감사드립 니다.

\section{참고문헌}

1. Peacy, J., Guo, X., J., and Robles, E., 2004: Copper Hydrometallurgy - Current Status, Preliminary Economics, Future Direction and Positionin verus Smelting, Transactions of Nonferrous Metals Society of China, 14(3), pp. 560-568.

2. Meng, X. and Han, K., N., 1996: The Principles and Applications of Ammonia Leaching of Metals - A Review, Mineral Processing and Extractive Metallurgy Review, 16, pp. 23-61.

3. Kim, S-K, 2010: The Main Contents of the Countermeasures for Recycling of Used Metal Resources, J. of Korean Inst. of Resources Recycling, 19(4), pp. 3-12.

4. Kim, E.-y., Kim, M.-s., Lee, J.-c., Jha, M. K., Yoo, K. and Jeong, J., 2008: Effect of Cuprous Ions on Cu Leaching in the Recycling of Waste PCBs, Using Electro-generated Chlorine in Hydrochloric Acid Solution, Minerals Engineering, 21, pp. 121-128.

5. Le, L., H., Yoo, K., Jeong, J. and Lee, J.-c., 2008: Leaching of Copper and Silver from Ground Mobile Phone Printed Circuit Boards Using Nitric Acid, J. of Korean Inst. of Resources Recycling, 17(3), pp. 48-55.

6. Lee, J.-c. et al, Development of Commercial Technology for Recovering Precious Metals, MOST/MOE, 2003.

7. Lee, J.-c. et al, Development of Recycling Technique for Waste Electric anc Eletronic Equipments, MOST (Ministry of Science and Technology) / MOE (Ministry of Environment), 2010.

8. Kim, J. H. et al., 2010: Recovery of Nickel from Spent Petroleum Catalyst by Hydrometallurgical Process, J. of the Korean Oil Chemists Soc., 27(3), pp. 273-281.

9. Kim, J. H. et al., 2010: Recovery of Tungsten from WC-Co Hardmetal Sludge by Aqua Regia Treatment, J. of Korean Inst. of Resources Recycling, 19(4), pp. 41-50.

10. Park, K.-H., Kim H.-I., and Lee, J.-Y., 2008: Leaching and Precipitation of Vanadium in Ammoniacal Solution, J. of Korean Inst. of Resources Recycling, 17(1), pp. 38-42

11. Kim, E.-y., Lee, S.-k., and Park, K.-H., 2006: Selective Leaching of Vanadium and Nickel in Metal Oxides Obtained from Orimulsion Ash, J. of Korean Inst. of Resources Recycling, 15(6), pp. 10-15.

12. Kim, J.-H., Yang, J.-G., and Lee, S.-S., 1995: Recovery of Valuable Metals from the Desulfurizing Spent Catalyst Used in Domestic Petrochemical Industry, J. of Korean Inst. of Resources Recycling, 4(3), pp. 2-9.

13. Kim, D. S., Chang, T. S., and Lee, Y. B., 1966: Aqueous Oxidation of Sulfide Ore (Part 1) Aqueous Oxidation of Marmatite in Ammonia Solution, Journal of the Korean 
Chemical Society, 10(2), pp. 54-58.

14. Lee, U. J., 1998: A Study on the Development of Hydrometallurgical Processes of Electric Arc Furnace Dust, Ministry of Science and Technology.

15. Lee, D. H. et al., 1985: Extraction of Nickel from Indonesian Low Grade Laterites: Electrochemical Leaching \& Purification of Leach Liquors, Ministry of Science and Technology.

16. Kim, H. J. et al., 1983: "New Dictionary of Chemistry", pp. 715, Bub-kyung, Seoul, Korea.

17. Luo, R., 1987: Overall Equilibrium Diagrams for Hydrometallurgical Systems: Copper-Ammonia-Water System, Hydrometallurgy, 17, pp. 177-199.

18. Bard, A. J., Parsons, R, and Jordan, J., 1985: "Standard Potentials in Aqueous Solution", pp. 250, 258, 288, 295, 314, 322, 340, Marcel Dekker, Inc., New York, USA.

19. Pourbaix, M., 1974: "Atlas of Electrochemical Equilibria in Aqueous Solutions", p. 323, National Association of Corrosion Engineers, Houston, USA.

20. Koyama, K., Tanaka, M., and Lee, J.-c., 2006: Copper Leaching Behavior from Waste Printed Circuit Board in Ammoniacal Alkaline Solution, Materials Transactions, 47(7), pp. 1788-1792.

21. Koyama, K., Tanaka, M., Miyasaka, Y., and Lee, J.-c., 2006: Electrolytic Copper Deposition from Ammoniacal Alkaline Solution Containing $\mathrm{Cu}(\mathrm{I})$, Materials Transactions, 47(8), pp. 2076-2080.

22. Majima, H., Nigo, S., Hirato, T., Awakura, Y., and IWAI M., 1993: Dissolution of Copper with Aqueous Cupric Ammine Solution - Studies on the Selective Recovery of Copper and Iron from Motor Scrap (1st Report), MMIJ, 109(3), pp. 191-194.

23. Zhou, K., Shinme, K., and Anezaki, S., 1995: Dissolution Rate of Copper in Aqueous Ammonia Solution Removal of Copper from Ferrous Scrap with Ammonia Leaching Method (1st Report), MMIJ, 111(1), pp. 49-53.

24. Zhou, K., Shnme, K., and Anezaki, S., 1995: Removal of Copper from Automobile Scrap - Removal of Copper from Ferrous Scrap with Ammonia Leaching Method (2nd Report), MMIJ, 111(1), pp. 55-58.

25. Zhou, K., Shnme, K., and Anezaki, S., 1996: Measurment of Copper Dissolution Rates in Aqueous Ammonia Solutions with Oxygen Circulating Ammonia Leaching Method, Metallurgical Review of MMIJ, 13(1), pp. 62-75.

26. Zhou, K., Shnme, K., and Anezaki, S., 1996: Copper Removal from Junk Automobile Scraps with Oxygen Circulating Ammonia Leaching Method, Metallurgical Review of MMIJ, 13(1), pp. 76-85.

27. Oishi, T., Koyama, K., Alam, S., Tanaka, M., and Lee, J.c., 2007: Recovery of High Purity Copper Cathode from
Printed Circuit Boards Using Ammoniacal Sulfate or Chloride Solutions, Hydrometallurgy, 89, pp. 82-88.

28. Sedzimir, J. and Bujanska, M., 1978: Kinetics of Leaching of Copper Metal in Copper(II)-Ammonium Sulphate Solutions as Determined by the Rotating Disc Method, Hydrometallurgy, 3, pp. 233-248.

29. Mironov, V. E., Pashkov, G. L., and Stupko, T. V., 1992: Thermodynamics of Formation Reactions and Hydrometallurgical Application of Metal-Ammonia Complexes in Aqueous Solutions, Russian Chemical Reviews, 61(9), pp. 944-958.

30. Nigo, S., Majima, H., HIrato, T., Awakura, Y., and Iwai M., 1993: Recovery of Copper from Motor Scrap Utilizing Ammonia Leaching Technique - Studies on the Selective Recovery of Copper and Iron from Motor Scrap (2nd Report), MMIJ, 109(5), pp. 337-340.

31. Oishi, T., Koyama, K., Konishi, H., Tanaka, M., and Lee, J.-c., 2007: Influence of Ammonium Salt on Electrowinning of Copper from Ammoniacal Alkaline Solutions, Electrochimica Acta, 53, pp. 127-132.

32. Oishi, T., Yaguchi, M., Koyama, K., Tanaka, M., and Lee, J.-c., 2008: Hydrometallurgy Process for the Recycling of Copper Using Anodic Oxidation of Cuprous Ammine Complexes and Flow-Through Electrolysis, Electrochimica Acta, 53, pp. 2585-2592.

33. Oishi, T., Yaguchi, M., Koyama, K., Tanaka, M., and Lee, J.-c., 2008: Effect of Phosphate on Lead Removal during a Copper Recycling Process from Waste Using Ammoniacal Chloride Solution, Hydrometallurgy, 90, pp. 161-167.

34. Bari, F., Begum, N., Jamaludin, S. B., and Hussin, K., 2009: Selective Leaching for the Recovery of Copper from PCB, Proceedings of the Malaysian Metallurgical Conference '09 (MMC09), December 1-2, Perlis, Malaysia, pp. 1-4.

35. Chang, C.-J. and Liu, J. C., 1998: Feasibility of Copper Leaching from an Industrial Sludge Using Ammonia Solutions, Journal of Hazardous Materials, 58, pp. 121132.

36. Aylmore, M. G., 2005: "Alternative Lixiviants to Cyanide for Leaching Gold Ores", In: Adams, M. D. (Eds.), Advances in Gold Ore Processing, pp. 501-560, Elsevier B. V., Amsterdam, Netherlands.

37. Marsden, J. O. and House, C. L., 2006: "The Chemistry of Gold Extraction”, pp. 233-295, Society for Mining, Metallurgy, and Exploration, Inc., Colorado, USA.

38. Aylmore, M. G. and Muir, D. M., 2001: Thiosulfate Leaching of Gold - A Review, Minerals Engineering, 14(2), pp. 135-174.

39. Jeffrey, M. I., 2001: Kinetic Aspects of Gold and Silver Leaching in Ammonia-Thiosulfate Solutions, Hydro- 
metallurgy, 60, pp. 7-16.

40. Breuer, P. L. and Jeffrey, M. I., 2002: An Electrochemical Study of Gold Leaching in Thiosulfate Solutions Containing Copper and Ammonia, Hydrometallurgy, 65, pp. 145-157.

41. Breuer, P. L. and Jeffrey, M. I., 2000: Thiosulfate Leaching Kinetics of Gold in the Presence of Copper and Ammonia, Minerals Engineering, 13(10-11), pp. 1071-1081.

42. Senanayake, G., 2012: Gold Leaching by Copper (II) in Ammoniacal Thiosulphate Solutions in the Presence of Additives. Part I: A Review of the Effect of Hard-Soft and Lewis Acid-Base Properties and Interactions of Ions, Hydrometallurgy, 115-116, pp. 1-20.

43. Senanayake, G. and Zhang, X. M., 2012: Gold Leaching by Copper (II) in Ammoniacal Thiosulphate Solutions in the Presence of Additives. Part II: Effect of Residual Cu (II), $\mathrm{pH}$ and Redox Potentials on Reactivity of Colloidal Gold, Hydrometallurgy, 115-116, pp. 21-19.

44. Feng, D. and van Deventer, J. S. J., 2006: Ammoniacal Thiosulphate Leaching of Gold in the Presence of Pyrite, Hydrometallurgy, pp. 126-132.

45. Feng, D. and VAn Deventer, J. S. J., 2010: Effect of Thiosulphate Salts on Ammoniacal Thiosulphate Leaching of Gold, Hydrometallurgy, pp. 120-126.

46. Alonso-Gomez, A. R. and Lapidus, G. T., 2009: Inhibition of Lead Solubilization during the Leaching of Gold and Silver in Ammoniacal Thiosulfate Solutions (Effect of Phosphate Addition), Hydrometallurgy 99, pp. 89-96.

47. Arima, H., Fujita, T. and Yen, W.-T., 2004: Using Nickel as a Catalyst in Ammonium Thiosulfate Leaching for Gold Extraction, Materials Transactions, 45(2), pp. 516-526.

48. Zipperian, D., Raghavan, S. and Wilson, J. P., 1988: Gold and Silver Extraction by Ammoniacal Thiosulfate Leaching from a Rhyolite Ore, Hydrometallurgy, 19, pp. 361-375.

49. Zheng, J., Ritchie, I. M., La Brooy, S. R., and Singh, P., 1995: Study of Gold Leaching in Oxygenated Solutions Containing Cyanide-Copper-Ammonia Using a Rotating Quartz Crystal Microbalance, Hydrometallurgy, 39, pp. 277-292.

50. Jeffrey, M. I., Linda, L., Breuer, P. L., and Chu, C. K., 2002: A kinetic and Electrochemical Study of the Ammonia Cyanide Process for Leaching Gold in Solutions Containing Copper, Minerals Engineering, 15, pp. 11731180.

51. Muir, D. M., 2011: A Review of the Selective Leaching of Gold frome Oxidised Copper-Gold Ores with AmmoniaCyanide and New Insights for Plant Control and Operation, Minerals Engineering, 24, pp. 576-582.

52. Meng, X. and Han, K. N., 1993: The Dissolution Behavior of Gold in Ammoniacal Solutions, In: HIskey, J. B. and Warren, G. W. (Eds.), Hydrometallurgy - Fundamentals, Technology and Innovation, SME Littleton, Co, Printed by Cushing-Malloy, Ann Arbor, MI, pp. 205-221.

53. Dasgupta, R., Guan, Y. C., and Han, K. N., 1997: The Electrochemical Behavior of Gold in Ammoniacal Solutions at $75^{\circ} \mathrm{C}$, Metallurgical and Materials Transactions B, 28B, pp. 5-12.

54. Han, K. N. and Fuerstenau, M. C., 2000: Factors influencing the rate of dissoluton of gold in ammoniacal solutions, International Journal of Mineral Processing, 58, pp. 369-381.

55. Peri, K., Guan, Y. and Han, K. N., 2001: Dissolution Behavior of Gold in Ammoniacal Solutions with Iodine as an Oxidant, Minerals \& Metallurgical Processing, 18(1), pp. 13-17.

56. Bhuntumkomol, K., Han, K. N., and Lawson, F., 1982: The Leaching Behavior of Nickel Oxides in Acid and in Ammoniacal Solutions, Hydrometallurgy, 8, pp. 147-160.

57. Nikoloski, A. N. and Nicol, M. J., 2010: The Electrochemistry of the Leaching Reactions in the Caron Process II. Cathodic Processes, Hydrometallurgy, 105, pp. 54-59.

58. Senanayake, G., Senaputra, A., and Nicol, M. J., 2010: Effect of Thiosulfate, Sulfide, Copper(II), Cobalt(II)/(III) and Iron Oxides on the Ammonical Carbonate Leaching of Nickel and Ferronickel in the Caron Process, Hydrometallurgy, 105, pp. 60-68.

59. Jandova, J. and Pedlik, M., 1994: Leaching Behaviour of Iron-Nickel Alloys in Ammoniacal Solution, Hydrometallurgy, 35, pp. 123-128.

60. Chander, S. and Sharma, V. N., 1981: Reduction Roasting/ Ammonia Leaching of Nickeliferous Laterites, Hydrometallurgy, 7, pp. 315-327.

61. Han, K. N., Nebo, C. O., and Ahmad, W., 1987: The Leaching Kinetics of Cobalt and Nickel form AluminumCoprecipitated Products, Metallurgical Transactions B, 18B, pp. 635-640.

62. Katsiapi, A., Tsakiridis, P. E., Oustadakis, P., and AgatziniLeonardou, S., 2010: Cobalt Recovery from Mixed Co-Mn Hydroxide Precipitates by Ammonia-Ammonium Carbonate Leaching, Minerals Engineering, 23, pp. 643-651.

63. Yoo, K. et al., 2011: Mineral Processing Technologies for Deep-Seabed Resources; A Review, J. KSGE, 48(6), pp. 821-828.

64. Park, K.-H., Mohapatra, D., Reddy, B. R., and Nam C.-W., 2007: A Study on the Oxidative Ammonia/Ammonium Sulphate Leaching of a Complex (Cu-Ni-Co-Fe) Matte, Hydrometallurgy, 86, pp. 164-171.

65. Niinae, M., Komatsu, N., Nakahiro, Y., Wakamatsu, T., and Shibata, J., 1996: Preferential Leaching of Cobalt, 
Nickel and Copper from Cobalt-Rich Ferromanganese Crusts with Ammoniacal Solutions Using Ammonium Thiosulfate and Ammonium Sulfite as Reducing Agents, 40, pp. 111-121.

66. Jana, R. K., Pandey, B. D., 1999: Ammoniacal Leaching of Roast Reduced Deep-sea Manganese Nodules, Hydrometallurgy, 53, pp. 45-56.

67. Mishra, D., Srivastava, R. R., Sahu, K. K., Singh, T. B., and Jana, R. K., 2011: Leaching of Roast-reduced Manganese Nodules in $\mathrm{NH}_{3}-\left(\mathrm{NH}_{4}\right)_{2} \mathrm{CO}_{3}$ Medium, Hydrometallurgy, 109, pp. $215-220$

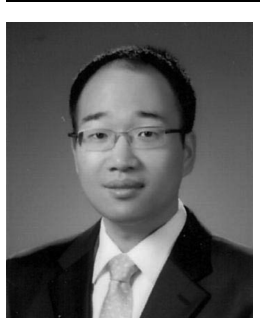

\section{柳 庚 槿}

- 한양대학교 자원공학과 학사

- 한양대학교 자원환경공학과 석사

- Hokkaido University 환경자원공학 박사

- 한국지질자원연구원 선임연구원

- 현재 한국해양대학교 에너지자원공 학과 조교수
68. Demidov, A. I. and Krasovitskaya, O. A., 2001: Kinetics of Leaching of Nickel Compounds from Spent Electrodes of Nickel-Iron Batteries in Ammonia Solutions, Russian Journal of Applied Chemistry, 74(5), pp. 737-741.

69. Salhi, R., 2010: Recovery of Nickel and Copper from Metal Finishing Hydroxide Sludges by Ammoniacal Leaching, Mineral Processing and Extractive Metallurgy, 119(3), pp. $147-152$.

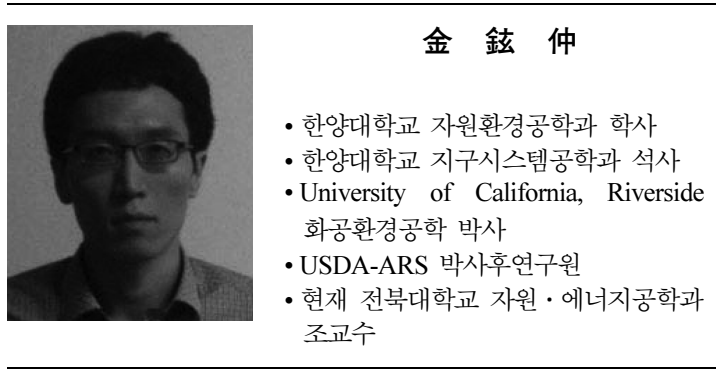

